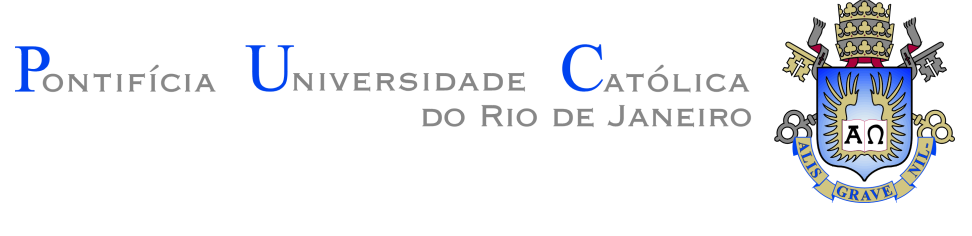

Robert Pablo Urbina Rodriguez

\title{
Use of Credit in Times of Covid-19: \\ Evidence from Peru
}

\section{Dissertação de Mestrado}

Thesis presented to the Programa de Pós-graduação em Economia, do Departamento de Economia da PUC-Rio in partial fulfillment of the requirements for the degree of Mestre em Economia.

Advisor: Prof. Carlos Viana de Carvalho

Co-advisor: Prof. Eduardo Zilberman 


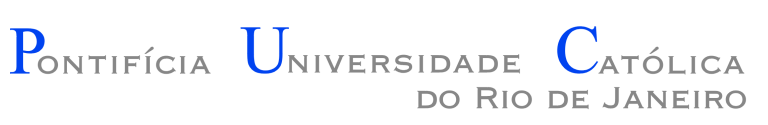

Robert Pablo Urbina Rodriguez

\section{Use of Credit in Times of Covid-19: \\ Evidence from Peru}

Thesis presented to the Programa de Pós-graduação em Economia, do Departamento de Economia da PUC-Rio in partial fulfillment of the requirements for the degree of Mestre em Economia. Approved by the Examination Committee:

Prof. Carlos Viana de Carvalho

Advisor

Departamento de Economia - PUC Rio

Prof. Eduardo Zilberman

Co-advisor

Departamento de Economia - PUC Rio

Prof. Daniel da Mata

Departamento de Economia - FGV

Prof. Juliano Assunção

Departamento de Economia - PUC Rio

Rio de Janeiro, October the 1th, 2021 
All rights reserved.

Robert Pablo Urbina Rodriguez

B. A. in Economics, the National University of San Marcos (Lima, Peru), 2013.

Bibliographic data

Urbina Rodriguez, Robert Pablo

Use of Credit in Times of Covid-19: Evidence from Peru Robert Pablo Urbina Rodriguez; advisor: Carlos Viana de Carvalho; co-advisor: Eduardo Zilberman. - 2021.

48 f: il. color. ; $30 \mathrm{~cm}$

Dissertação (mestrado) - Pontifícia Universidade Católica do Rio de Janeiro, Departamento de Economia, 2021.

Inclui bibliografia

1. Economia - Teses. 2. Pandemia Covid-19. 3. Transferências de dinheiro. 4. Uso do crédito. 5. Heterogeneidade populacional. I. Carvalho, Carlos Viana de. II. Zilberman, Eduardo. III. Pontifícia Universidade Católica do Rio de Janeiro. Departamento de Economia. IV. Título. 


\section{Acknowledgments}

I would like to thank my advisors Prof. Carlos Viana and Prof. Eduardo Zilberman, whose valuable comments and contributions were essential to this research. Any mistakes are my own.

I am thankful to my parents, Candelaria and Pablo, and my brother Grezzly, for always believing in me and pushing me forward. I am especially thankful to Guadalupe, for his endless support and companionship. This would not have been possible without the constant motivation of the four of you. A special thanks to Mario Huarancca, who gave me access to a first version of the SISFOH dataset, widely used in this work.

Finally, my experience at PUC would not have been the same without the company of all my classmates. However, I would especialy like to thank the friendship of Luizão and Mateuzão, with whom I have good memories that will last a lifetime.

This study was partly financed by the Coordenação de Aperfeiçoamento de Pessoal de Nível Superior - Brasil (CAPES) - Finance Code 001. 


\section{Abstract}

Urbina Rodriguez, Robert Pablo; Carvalho, Carlos Viana de (Advisor); Zilberman, Eduardo (Co-advisor). Use of Credit in Times of Covid-19: Evidence from Peru. Rio de Janeiro, 2021. 48p. Dissertação de mestrado - Departamento de Economia, Pontifícia Universidade Católica do Rio de Janeiro.

This paper analyzes the use of credit during the Covid-19 pandemic in the context of a cash transfer program. Under a Difference-in-Differences approach, I show causal evidence of how the implementation of a cash transfer program impacted the population's credit use patterns, using a combined set of microdata: SISFOH (a household targeting system), the national household survey, and the credit register for Peru. Exploring a discontinuity in the rule for granting emergency income to the poorest population, I show that individuals who received a monetary subsidy increased their total lending in the financial system, in contrast to those individuals who did not. This is worrisome as it is also presented an increase in the interest rates and days of arrears. Furthermore, I also explore some dimensions of population heterogeneity (education, age, gender, informality, among others), finding a differentiated impact according to certain characteristics of individuals. I put a special effort into the informality analysis since, even in the absence of an exogenous identification, this variable presents significant results and passes certain tests of identification.

\section{Keywords}

Covid-19; lending in the financial system; credit use patterns; population heterogeneity; income transfers; cash transfers; use of credit. 


\section{Resumo}

Urbina Rodriguez, Robert Pablo; Carvalho, Carlos Viana de; Zilberman, Eduardo. Uso do Crédito em Tempos de Covid-19: Evidência Baseada em Microdados do Peru. Rio de Janeiro, 2021. 48p. Dissertação de Mestrado - Departamento de Economia, Pontifícia Universidade Católica do Rio de Janeiro.

Este artigo analisa o uso de crédito durante a pandemia Covid-19 no contexto de um programa de transferência de renda. Sob uma abordagem Diferença em Diferenças, eu mostro evidências causais de como a implementação de um programa de transferência de renda impactou os padrões de uso de crédito da população, usando um conjunto combinado de microdados: SISFOH (um sistema de focalização familiar), a pesquisa domiciliar nacional e o registro de crédito para o Perú. Explorando uma descontinuidade na regra de concessão de renda emergencial à população mais pobre, mostro que os indivíduos que receberam um subsídio monetário aumentaram seu total de empréstimos no sistema financeiro, ao contrário daqueles que não o fizeram. Isso é preocupante, pois também se apresenta um aumento nas taxas de juros e dias de atraso. Além disso, também exploro algumas dimensões da heterogeneidade populacional (educação, idade, gênero, informalidade, entre outras), encontrando um impacto diferenciado de acordo com certas características dos indivíduos. Fiz um esforço especial na análise da informalidade, pois, mesmo na ausência de uma identificação exógena, essa variável apresenta resultados significativos e passa em certos testes de identificação.

\section{Palavras-chave}

Covid-19; empréstimos no sistema financeiro; padrões de uso do crédito; heterogeneidade da população; transferências de renda; transferências de dinheiro; uso do crédito. 


\section{Contents}

I. Introduction 11

II. Peruvian Background Information and Datasets 14

A. Covid Policies in Peru .

B. Peruvian Data and Summary Statistics 16

III. Methodology 20

A. Identification of The CSE 20

A.1. Computing the IFH 21

B. Diff-in-Diff Implementation 24

IV. Results $\quad 26$

A. Robustness . . 34

$\begin{array}{ll}\text { V. Conclusion } & 38\end{array}$

$\begin{array}{ll}\text { VI. References } & 39\end{array}$ 


\section{List of Figures}

1. Composition of Data by Characteristics 19

2. Methodology for Determining the CSE 22

3. Parallel Trends for Cash Transfers 26

4. Parallel Trends for Informality 31 


\section{List of Tables}

1. Evolution of Informal Labor and Poverty Rates 14

2. Financial Grants Provided by the Peruvian government 15

3. Descriptive Statistics . 17

4. Effects of the Implementation of the Financial Aid on Credit Demand and Interest Rates 28

5. Effects of the Implementation of the Financial Aid on Days of Arrears

6. Effects of the Covid-19 pandemic on Credit Demand and Interest Rates

7. Effects of the Covid-19 Pandemic on Days of Arrears 34

8. Falsification Test: Cash Transfers 35

9. Falsification Test: Labor Informality 36

10. Placebo test . 37

11. Urban Area Cluster $\quad$. 41

12. Rural Area Cluster . . 42

13. Gender . . 43

14. Civil Status . . 44

15. Level of Education . . 45

16. Job Sector . 46

17. Geographic Region . . 47

18. Age . 48 


\section{List of Abbreviations}

CSE: Socioeconomic classification

DiD: Difference-in-Differences

ENAHO: Peruvian household survey

INEI: National Institute of Statistics and Informatics

IFH: Household targeting index

MIDIS: Ministry of Development and Social Inclusion

PCA: Principal components analysis

RCC: Credit register

SBS: Peruvian Bank Regulator

$\mathrm{S} /$ : soles 


\section{Introduction}

The Covid-19 pandemic represented an unexpected and quite considerable shock, which brought with it a series of effects on economic activity (Fezzi, C. and Fanghella, V. (2020); Deb, P., et. at. (2020)), employment (Aum, S., et. at. (2021)), environment (Rume, T. and Didar-Ul, S.M. (2020)), among others. This virus has not differentiated between races or genders, and although some sectors are more affected, all have felt in some way the consequences that this pandemic brought with it. In this sense, a diversity of research has emerged where a variety of topics have been addressed, especially those related to the effectiveness of government assistance in this emergency situation.

Government aid seeks to provide some kind of relief to cover the cost of living; thus, some countries have adopted programs to distribute food or services at a low cost. For instance, Berkouwer, S., et. al. (2021) show that electricity transfers not only enables an immediate government response to the crisis, but also there are individuals who prefer electricity transfers over cash. Nevertheless, despite this, the majority of countries have implemented cash transfer policies towards vulnerable populations. Peru is no stranger to this and, during the second and third quarter of 2020, implemented a continuous scheme of money transfers.

In this paper, I use the implementation of a cash transfer policy in Peru to provide causal evidence that this policy can have the unintended consequence of inducing individuals to borrow more, as there was not a good communication of the requirements to be considered in this public policy towards the population. This is important, as the objective of the policy is to provide liquidity to those individuals in poverty who were in confinement and who did not receive any income at that time. However, the increase in their credit without any other increase in their income caused an increase in the days of arrears and interest rates, which leaves them even more vulnerable than at the beginning.

My identification strategy rests on a discontinuity in the rule for granting emergency income to the poorest population. This rule is based on the SISFOH dataset, a register that contains information of Peruvian citizens related to personal characteristics, living conditions, level of education, among others. In this way, using this register is possible to approximate the socioeconomic classification of individuals and, as a result, identify those individuals that are part of the prioritized population groups (poor population). In particular, I 
replicated the methodology for determining the socioeconomic classification of the Ministry of Development and Social Inclusion of Peru, which use the Principal Components Analysis method to select some living indicators that are used in the construction of the Household Targeting Index (IFH), an aggregated and continuous indicator that allows me to classify a person as poor or non-poor. As living conditions to determine a poor individual are completely different among regions, the IFH index is established for 15 geographic clusters composed of combinations of eight identifiable geographic domains and the rural indicator. Furthermore, once the IFH index was computed, I restrict my sample by only using those individuals near the cutoff and, as a result, I did not just differentiate between those individuals who benefited from the cash transfer policies and those who do not, but also I made sure to include only those individuals who were on the verge of belonging to the other group. Thus, my treatment/control group is composed by those individuals above/below the cutoff point of this restricted sample.

After the identification of the treatment and control group, I got their credit information between January of 2019 and June of 2021 and, using a Differencein-Differences (DiD) framework, I estimated the effect of the implementation of the cash transfers policies on the indebtedness of individuals. I performed four different regressions where I go from a general specification, to a totally restricted one where I included individuals and bank-date fixed effects, as well as some variables to control possible preferences of a person to deal with a particular financial institution. Furthermore, as Saurina et. al. (2012) and Alfaro et. al. (2019) specify, I disentangle demand from supply effects as I have data of loans from individuals who have demanded in one or more banks. To implement my identification strategy, I rely on confidential registers, to which I had access through the central bank. My dataset includes the loan-level data of all lending activities of banks since january of 2019 to june of 2021, for individuals previously identified through the SISFOH register.

My findings indicate cash transfers policy in a context of bad communication (by the government) can be counterproductive as motivate individuals to increase their credit demand above their ability to pay and, as a result, to increase their days of arrears and the cost of their future financing. This is motivated by the belief that individuals would receive the financial aid more than once. In particular, the cash transfer policy is responsible for an increase of $1.4 \%$ in credit demand, $3.2 \%$ of days of arrears, and 7 basis points in interest rates for individuals who receive this financial aid. To complement my analysis, I include the placebo and falsification tests that support the causality of my findings, as well as the parallel trends between the two groups of individuals.

Then I also explore some dimensions of population heterogeneity such as ed- 
ucation, age, gender, job sector, geographic region, civil status and informality. I put an special effort on the latter, as informality is a topic of extensive research, what is particularly important in a developing country such as Peru, where the rate of labor informality is close to $70 \%$, with a very little decline over the last years. To this purpose, I also used the household survey for Peru, as this report helps me to construct indicators on living conditions, in particular those related to informal activities. The household survey is a public database with national representation that has information on (unidentified) individuals distributed throughout the Peruvian territory. In this case, I also got access the identifiers of each person included in this survey and thus, I was able to get a complete database with the credit information of these individuals. With this, I used a DiD specification and although in this case I cannot assure the existence of a causal identification, I provide evidence that this dataset also complies with the parallel trends and the falsification test implemented for cash transfers. In particular, informal workers seem to have an increase of $5.7 \%$ in their credit, $20 \%$ in their days of arrears and 59.7 basis points in their interest rates.

Last but not least, although the literature related to covid-19 has developed extensively, this is the first paper (as far as I can know) that analyzes empirically the impact of a cash transfer policy on credit using microdata. In general, Perú offers a great laboratory to test whether individuals respond to the cash-transfer program in Covid-19 times, as was one of the first countries to apply quarantine. Furthermore, as the Peruvian government implemented a variety of policies that were in line with the rest of the countries (some of them with similar characteristics), the conclusions and recommendations of this paper are likely to apply more broadly, especially developing economies. This is because the setting in the majority of developing countries is very similar to that of Perú, like the underdeveloped financial system or the proportion of informality. Furthermore, cash transfer policies were implemented similarly in many countries around the globe. Again, this paper take advantage of the availability of the credit microdata of the Peruvian individuals, as well as some other confidential and compulsory registers that make possible for me to assess the impact of cash transfers on the use of credit during the Covid-19 pandemic.

The rest of the paper is divided as follows: in Section II I show the peruvian background information related to the Covid-19 context and the datasets used; Section III explains the methodology used and the model implemented; Section IV shows the results and Section V gives the conclusions. Some extra information is added at the end of the work in the Appendices included. 


\section{Peruvian Background Information and Datasets}

The Covid-19 pandemic is an unexpected event that brought with it a paralysis in economic activity (due to quarentine decreed in many countries), which mainly affected individuals living in poverty, as well as those with an informal job.

Peru was no stranger to this, and the impact was even more pronounced as it is a country with a high rate of monetary poverty and a rate of labor informality even higher that remained almost constant over the last years. Table 1 shows the evolution of informal labor and poverty rates over the last years in Peru. In particular, before the Covid-19 pandemic, the informal labor remained almost constant over the last years by approximately $73 \%$; however, with preliminary data for 2021, it is observed a steep rise in the informal labor rate up to $77.3 \%$. It can be observed a similar behaviour for monetary poverty, in which over the last years was by about $21 \%$ with exception of 2020 , where due to the pandemic, monetary poverty increase up to $30.1 \%$. Similar case we observe in extreme poverty; in this case, it is observed an increase of $2.2 \%$ in extreme poverty up to $5.1 \%$ in 2020 .

\begin{tabular}{ccc|cc|cc}
\hline & \multicolumn{2}{c|}{ Informal Labor } & \multicolumn{2}{c|}{ Monetary Poverty } & \multicolumn{2}{c}{ Extreme Poverty } \\
\hline & Rate & Var. & Rate & Var. & Rate & Var. \\
\hline \hline 2014 & $73.5 \%$ & $-0.4 \%$ & $22.7 \%$ & $-1.2 \%$ & $4.3 \%$ & $-0.4 \%$ \\
2015 & $73.1 \%$ & $-0.4 \%$ & $21.8 \%$ & $-0.9 \%$ & $4.1 \%$ & $-0.2 \%$ \\
2016 & $72.6 \%$ & $-0.5 \%$ & $20.7 \%$ & $-1.1 \%$ & $3.8 \%$ & $-0.3 \%$ \\
2017 & $72.0 \%$ & $-0.6 \%$ & $21.7 \%$ & $+1 \%$ & $3.8 \%$ & $0 \%$ \\
2018 & $72.7 \%$ & $+0.7 \%$ & $20.5 \%$ & $-1.2 \%$ & $2.8 \%$ & $-1 \%$ \\
2019 & $72.5 \%$ & $-0.2 \%$ & $20.2 \%$ & $-0.3 \%$ & $2.9 \%$ & $+0.1 \%$ \\
2020 & $72.7 \%$ & $+0.2 \%$ & $30.1 \%$ & $+9.9 \%$ & $5.1 \%$ & $+2.2 \%$ \\
2021 & $77.3 \%$ & $+4.6 \%$ & n/a & n/a & n/a & n/a \\
\hline
\end{tabular}

Table 1: Evolution of Informal Labor and Poverty Rates

Note: The information is obtained from the Peruvian household survey (ENAHO) and the Annual Report of the National Institute of Statistics and Informatics (INEI). Information of informality for 2021 is preliminary and corresponds to the first seemester of the year.

\section{A. Covid Policies in Peru}

The Peruvian government implemented some policies in order to face the crisis 
generated by the pandemic. For firms, the government implemented a monetary subsidy for employers in the private sector who have payroll workers who earn up to S/ 1,500; as well as the Reactiva program, with the aim of providing financing to companies at a low cost (interest rate near to zero) ${ }^{1}$.

\begin{tabular}{lll}
\hline \multicolumn{1}{c}{$\begin{array}{c}\text { Yo me quedo en } \\
\text { casa }\end{array}$} & \multicolumn{1}{c}{$\begin{array}{c}\text { Bono } \\
\text { Independiente }\end{array}$} & \multicolumn{1}{c}{ Bono Rural } \\
\hline \hline - Monetary subsidy of & - Monetary subsidy of & - Monetary subsidy of \\
S/ 380. & S/ 760. & S/ 760. \\
- Households living in & - Households living in & - Households in rural \\
poverty or extreme & poverty or extreme & areas living in poverty \\
poverty. & poverty. & or extreme poverty. \\
- Households located in & - Cannot be a & - Households that have \\
the geographic areas & beneficiary of any cash & not benefited from \\
with the highest health & transfer program & other economic support \\
risk during the state of & (Juntos, Pensión 65 & or receive help from \\
emergency due to the & and Contigo), nor from & social programs during \\
Covid-19. & previous Covid-grants. & the national emergency \\
& - Members of the & due to COVID-19. \\
& household must not be & \\
& registered as dependent & \\
& workers in the public or & \\
& private sector. & \\
& - Members of the & \\
& household must not \\
& generate income greater & \\
& than S/ 1,200.
\end{tabular}

Table 2: Financial Grants Provided by the Peruvian government

Note: The information is obtained from the official website of the Peruvian government: https://www.gob.pe. The assignation of the subsidies began in April of 2020 with a first group. Subsequently, new groups of individuals were incorporated, either with each new program, or through new versions of existing programs. However, most of times, even when they had not yet made the effective collection of the subsidy, they already knew that they were beneficiaries of these.

For individuals, in whom I am interested for my analysis, the government provided a series of various financial grants to help individuals affected by the isolation and mandatory social immobilization dictated by the COVID-19 crisis. Among the subsidies are the bono yo me quedo en casa, bono independi-

\footnotetext{
${ }^{1}$ This financing is guaranteed by the government and there exist some requirements that companies must have in order to be consider in the Reactiva program. The Central Bank of Perú was in charge of create la methodology behind this program. For further information, see https://www.mef.gob.pe/es/?option=com_content\&language=es-ES\&Itemid= $102665 \& l$ ang $=e s-E S \& v i e w=a r t i c l e \& i d=6429$.
} 
ente and bono rural ${ }^{2}$. Table 2 summarizes the requirements to be a beneficiary of each one of these programs.

The idea of these cash transfers was to reach all individuals in vulnerable situations. The government of Perú identify those individuals through the SISFOH register, as it allows them to select those indivuals listed as "poor" or "extreme poor" in that register ${ }^{3}$. As can be observed, there is a requirement related to the previous participation in any Covid-19 program; in this sense, to be considered in the financial aid of the Peruvian government in the Covid-19 context, individuals must not have received any other grant of this type. The only exception is for the Yo me quedo en casa program, which was the first implemented.

\section{B. Peruvian Data and Summary Statistics}

Most of the data used in this work relies on compulsory and confidential reports. Thus, in this section I explain the datasets I work with.

First of all, I use the credit information, which is obtained from the credit register (RCC) and is reported to the Peruvian Bank Regulator ( $\mathrm{SBS}^{4}$ ) and constitute the main dataset used in this work. This report records the credit information of all individuals and firms in a monthly frequency. In particular, I work with the monthly balances of all loans made by the universe of individuals of the Peruvian financial system. Thus, I work with the total financial indebtedness of individuals, which is made up of consumer loans and loans for business purposes. Although the RCC is a report sent to the SBS, it is also available for the Central Bank and that was the way the information was accessed.

I also use the Household Targeting System (SISFOH) register, a dataset that allows me to make the poverty identification. This register contains socioeconomic information on citizens and thus, through a methodology later explained, I can identify those individuals who are part of the prioritized population and will be able to access the government programs. The SISFOH dataset is a register that shows the Socioeconomic Classification (CSE) of individuals. To this purpose, the Peruvian population can make the request to this classification where they must complete a set of files with information related to living conditions. Within the required information is the number

\footnotetext{
${ }^{2}$ There are other programs also implemented in this context such the bono familiar universal. However, they are aimed at a broader target audience that is not the objective of the analysis of this paper.

${ }^{3}$ Depending of the program, there is a requirement not to be a beneficiary of any government program.

${ }^{4}$ Superintendence of Banks and Insurance Companies.
} 
and name of home appliances, accessibility to basic services (e.g., water), civil status, detailed level of education, among others.

\section{Credit Register:}

\begin{tabular}{lcccccc}
\hline & Mean & Median & SD & P5 & P95 & N.O. \\
\hline \hline Log(Total Credit) & 8,0 & 8,0 & 1,6 & 5,4 & 10,7 & $14,6 \mathrm{M}$ \\
Implicit Interest Rate (\%) & 3,2 & 2,1 & 4,5 & 0,5 & 9,7 & $11,3 \mathrm{M}$ \\
Number of bank relationships & 2,2 & 2,0 & 1,2 & 1,0 & 5,0 & $14,6 \mathrm{M}$ \\
Days of arrears - overdue debt & 218 & 51 & 930 & 2 & 856 & $3,0 \mathrm{M}$ \\
Length Relationship ${ }_{i, b}$ (months) & 12 & 14 & 5 & 1 & 15 & $14,6 \mathrm{M}$ \\
\% Credit with their main bank & 61,1 & 67,9 & 37,8 & 2,8 & 100 & $14,6 \mathrm{M}$ \\
\hline
\end{tabular}

\section{SISFOH and Credit Registers:}

\section{Control Group}

\begin{tabular}{lcccccc}
\hline & Mean & Median & SD & P5 & P95 & N.O. \\
\hline \hline Log(Total Credit) & 8,1 & 8,0 & 1,6 & 5,4 & 10,8 & $7,0 \mathrm{M}$ \\
Implicit Interest Rate (\%) & 3,1 & 2,1 & 4,4 & 0,5 & 9,1 & $5,4 \mathrm{M}$ \\
Number of bank relationships & 2,2 & 2,0 & 1,3 & 1,0 & 5,0 & $7,0 \mathrm{M}$ \\
Days of arrears - overdue debt & 217 & 50 & 1071 & 2 & 829 & $1,5 \mathrm{M}$ \\
Length Relationship ${ }_{i, b}$ (months) & 12 & 14 & 5 & 2 & 15 & $7,0 \mathrm{M}$ \\
\% Credit with their main bank & 59,8 & 64,4 & 38,0 & 2,5 & 100 & $7,0 \mathrm{M}$ \\
\hline
\end{tabular}

Treatment Group

\begin{tabular}{lcccccc}
\hline & Mean & Median & SD & P5 & P95 & N.O. \\
\hline \hline Log(Total Credit) & 8,0 & 7,9 & 1,6 & 5,4 & 10,7 & $14,6 \mathrm{M}$ \\
Implicit Interest Rate (\%) & 3,3 & 2,1 & 4,7 & 0,5 & 10,1 & $11,3 \mathrm{M}$ \\
Number of bank relationships & 2,1 & 2,0 & 1,2 & 1,0 & 4,0 & $14,6 \mathrm{M}$ \\
Days of arrears - overdue debt & 219 & 52 & 788 & 2 & 880 & $3,0 \mathrm{M}$ \\
Length Relationship ${ }_{i, b}$ (months) & 11 & 14 & 5 & 1 & 15 & $14,6 \mathrm{M}$ \\
\% Credit with their main bank & 62,4 & 71,3 & 37,6 & 3,1 & 100 & $14,6 \mathrm{M}$ \\
\hline
\end{tabular}

Table 3: Descriptive Statistics

Note: These statistics are obtained from the credit and SISFOH register. The first table corresponds to my total sample as a whole, where the column N.O. have information about the number of observations, specified in millions. The second and third table show the same financial information, but divided using the identification of the SISFOH register; thus, I show this information for my control and treatment group.

Furthermore, I use the National Household Survey to obtain the identification for informal work. This dataset is an annual survey that allows the National Institute of Statistics and Informatics to monitor the indicators on living conditions. It serves to generate indicators that allow knowing the evolution of poverty, welfare, education, the living conditions of households, among 
others. Although this information is published at the level of individuals, who remain anonymous, I had access to the identifier of the people (ID) to be able to merge this dataset with those previously mentioned. This correlator of IDs constitutes a confidential dataset and was accessed through the Central Bank of Peru.

I also work with some bank information obtained from the balance sheets of Banks such as deposits, assets, profitability and liquidity. Mostly of this information is public, but in particular I work with the information of the Central Bank's Monetary Analysis Department, as they compile all the monetary information at the bank level ${ }^{5}$. I also use some additional datasets that involves market data such as exchange rates, $\mathrm{BSI}^{6}$, among others.

Table 3 shows the summary statistics at the individuals-bank level for the variables included in my analysis. The information in this table is show for the complete period between January of 2019 and June of 2021. Thus, on average, individuals have little more than 2 bank relationships that last 12 months on average. Also, the overdue debt is 218 days past due and individuals have roughly $60 \%$ of their credit with their main bank. In the same table, I show these same statistics for my treatment and control group, where a balance is observed between both groups with similar values in the statistics of both groups.

Finally, Figure 1 shows how my data was composed by certain characteristics of individuals. I took February of 2020 as a reference for this Figure. In particular, by that month, more than $80 \%$ of the credit was in a normal condition; i.e., credit with no days of arrears. Furthermore, roughly $40 \%$ of individuals in my dataset are married, while almost $25 \%$ are single. On the other hand, even though my dataset has individuals who speak native languages, more than $80 \%$ are native Spanish-speaking individuals. In the case of education, the majority of individuals have some kind of education, where almost $50 \%$ have a high school. Last but not least, my dataset is composed of individuals in a variety of regions, although individuals living in urban areas predominate.

\footnotetext{
${ }^{5}$ This information is the same, although more complete and with greater details, than the information of the website of The Superintendency of Banking, Insurance and AFP (SBS).

${ }^{6}$ Institutional Sectoral Balance, that has the credit report disaggregated at the institutional sectors level.
} 


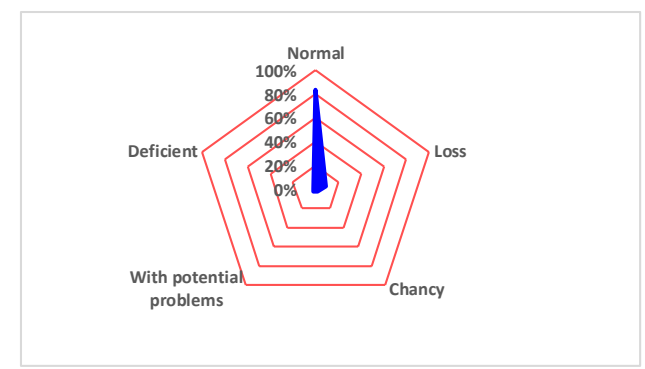

(a) Debt Category

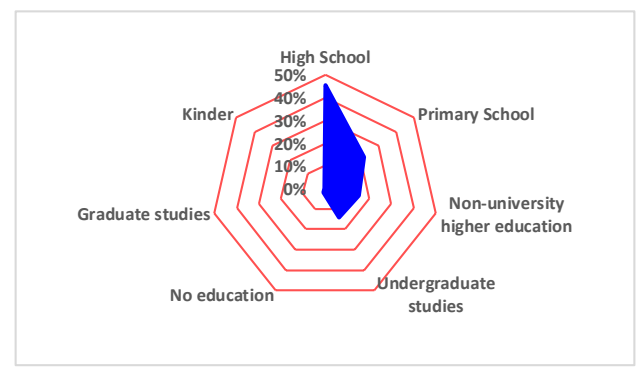

(c) Level of Education

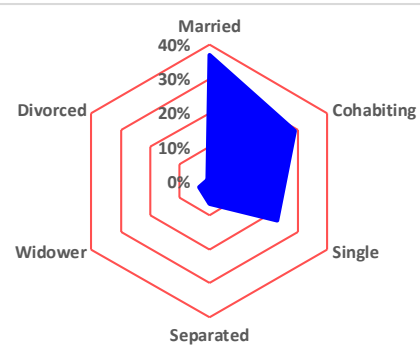

(b) Civil Status

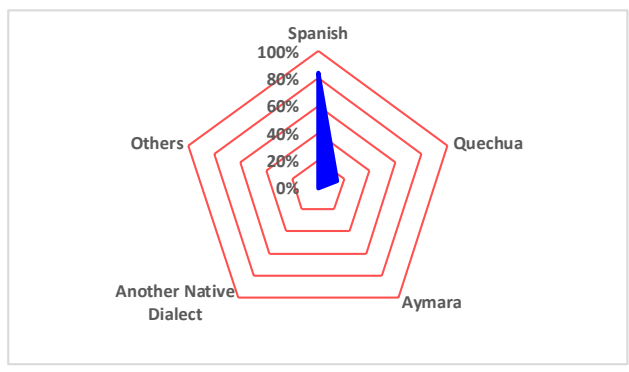

(d) Native Language

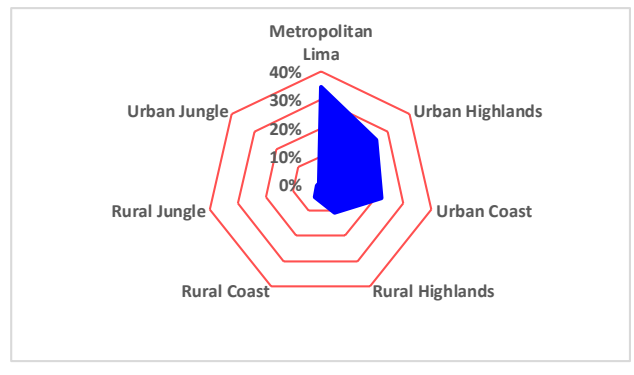

(e) Region

Figure 1: Composition of Data by Characteristics

Note: These figures correspond to my sample after merging the credit register and the SISFOH register; however, the indicators I show corresponds only to the SISFOH register. Thus, this figure shows the composition (in percentages) of some variables that I used to balance my sample. 


\section{Methodology}

My analysis is based on a two-stage process, where first I have to identify the socioeconomic classification (CSE) of each person, to later do the DiD implementation that shows causal evidence of cash transfers on the use of credit during the Covid-19 pandemic.

\section{A. Identification of The CSE}

On this stage, I find the CSE of individuals using the information provided by the SISFOH register, combined with the Ministerial Resolution 107-2015MIDIS (Methodology for Determining the Socioeconomic Classification). In practical terms, the CSE specifies if a person is considered poor or non-poor.

As it is observed in Figure 2, the methodology involves a 3-steps proccess that serves to identify the socioeconomic classification of a person, what is different for individuals in rural area, urban area (without Metropolitan Lima) and Metropolitan Lima. The first step corresponds to the evaluation of the per-capita income in the household, where a person is considered as non-poor if the per-capita income in the household is greater than a threshold (e.g., S/ 383 for Lima); if not, the second step is evaluated. In the second step the consumption of electricity is evaluated, where again a person is considered as non-poor if the per-capita consumption of electricity in the household is greater than a threshold (e.g., S/ 18 for Lima); if not, the third step is evaluated, where the computation of the targeting index (IFH) is needed.

The first and second step require data that is very specific and almost inaccessible. For this reason, less than $5 \%$ of the socioeconomic classifications are identified on these steps. Also, I leave out of my dataset those individuals whose CSE were identified in this part, since they are not useful for the identification of my paper. As I have the initial classification of those individuals whose CSE was identified in the first two steps, it is an easy task.

As a result, I need to compute the IFH index, what will allow me to identify the control (receive cash transfers) and treatment (do not receive cash transfers) groups, according to the methodology of the Peruvian government. 


\section{A.1. Computing the IFH}

To compute the Household Targeting Index (IFH) index, the Ministry of Development and Social Inclusion (MIDIS) developed a methodology, where the Principal Component Analysis (PCA) method is used to find those variables that are significant in the definition of poverty. The SISFOH register contains socioeconomic information of almost all Peruvian individuals ${ }^{7}$; however, this dataset by itself would not allow identifying the poor from those who are not. For this reason, the household survey is used, because not only has the same socioeconomic variables as the SISFOH register, but also information about revenues, consumption, credit, among other variables that allow a good identification of poor individuals. Although this survey only has information for a sample of individuals, the selection of individuals included on this is made to achieve national representation. Thus, once the identification of variables that has greater relation with poverty is done (through the construction of factors with the PCA method), I return to the SISFOH register and use the results and variables obtained previously to identify the socioeconomic classification of Peruvian population.

In the initial analysis, more than 140 variables of the household survey are included in the methodology that, as was recently explained, is made up of the following sequence of procedures:

1. Construction of the database with information of the household survey of Peru (ENAHO) that is collected annually by the National Institute of Statistics and Informatics (INEI).

2. Selection of variables, using as a criterion the correlation that they exhibit in relation to household welfare measures (for example, per capita household expenditure).

3. Principal Component Analysis.

4. Determination of their cut-off points.

As this methodology is given, I only replicate this with the information of the SISFOH register, in order to match exactly with those individuals they identify as poor.

\footnotetext{
${ }^{7}$ The population of Peru is 33 millions, of which 23 millions are included in my dataset. Obviously, the SISFOH register does not contain information of children, as their socioeconomic classification depends on their parents.
} 


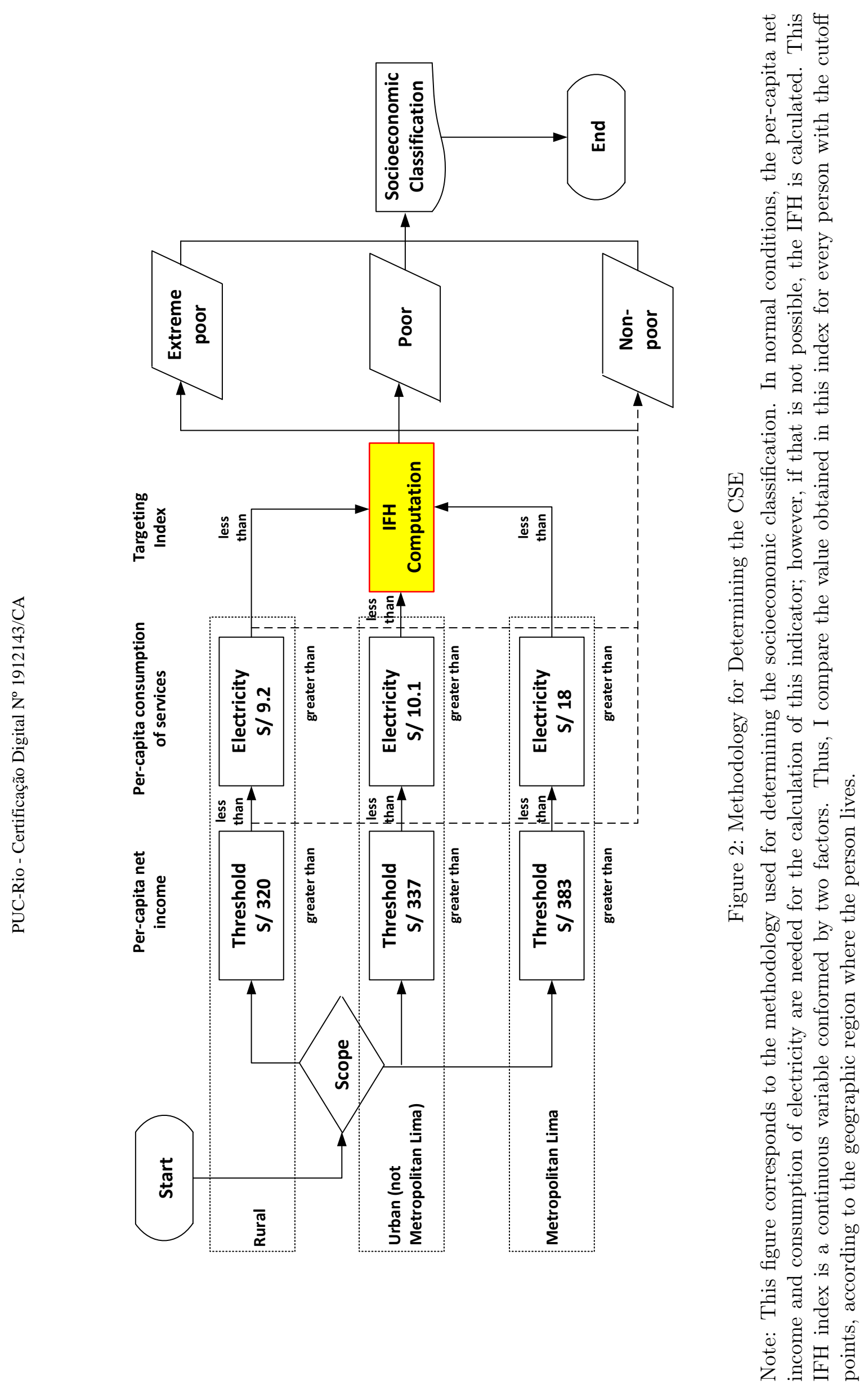




\section{Selection of variables through correlation analysis and temporal dynamics}

An 8-years period of household surveys is taken into account to capture the interrelationships between the various socioeconomic variables of the household with the state of poverty or the level of per-capita consumption, as well as capture different periods of the economy. Furthermore, in order to achieve more accurate inferences, a greater geographical disaggregation is made; thus, to estimate the IFH, it is established 15 geographic clusters composed of combinations of eight identifiable geographic domains and the rural indicator.

Then, an inspection is made of the variables that coincide between the single socioeconomic data sheet (part of the SISFOH register) and the household survey, taking into account variables that have a significant relationship with monetary poverty and with per-capita spending. Between those variables are those related to the access to basic services like electricity or water and sanitation, materials predominant in the construction of houses, among others.

With the initial selection of variables, the PCA method is implemented to get some factors most related with monetary poverty. The PCA method is a technique used for reducing the dimensionality of a dataset by ordering the components according to the amount of original variance they describe. However, PCA method does not allow only one method of selection of indicators since its nature is to capture the largest possible joint variance of the included variables; as a result, some variables with greater correlation with poverty or consumer spending were not finally included in the model, since their variance was already strongly explained by other variables.

The MIDIS mentioned that there are not a clear method to define what variables should be included. As a result, the selection of variables was determined by the following criteria: (i) To capture the greater possible quantity of important "dimensions" of the poverty, such as access to public services; (ii) to have a stable correlation over time; i.e., it is not expected to gain or lose predictive value with changes over time; (iii) to achieve high levels of area under the $\mathrm{ROC}^{8}$ curve; (iv) to obtain a factor normally distributed or that appears to be so; (v) in the case of having more than one factor for the conglomerate, unify them in such a way that joint predictive power is maximized ${ }^{9}$.

\section{Final Database}

The PCA method gives as results the tables showed in Appendix $\mathrm{A}^{10}$. With

\footnotetext{
${ }^{8}$ The receiving operating curves (ROC) present the predictive capacity of the index (in this case the principal component obtained by the PCA).

${ }^{9}$ The MIDIS demonstrate that the union of factors better predict the condition of poverty.

${ }^{10}$ As was mentioned before, this methodology and the results showed to the computation of the
} 
these tables and the cutt-off points provided in the Ministerial Resolution 107-2015-MIDIS, it is possible to construct the socioeconomic classificationof individuals that would allow me to implement my DiD specification, explained in the next subsection.

However, to be even more rigorous, I reduce my database using the IFH to keep only a restricted subsample. Specifically, I hold only a neighborhood around the IFH cutt-off points, in order to gain more precision in the results that will be displayed later. I tried to restrict this neighborhood as much as possible keeping the balance between the treatment and control group (given by the characteristics of individuals). As a result, I use a neighborhood of \pm 0.2 around the cutt-off points.

\section{B. Diff-in-Diff Implementation}

I use a difference-in difference model to compare difference in treated individuals' lending to that of individuals in the control group before and after the implementation of the financial aid from the peruvian government. The treatment group is composed by those individuals that, for very little, received the financial aid due to the quarantine decreed in the Covid-19 context; while the control group includes those individuals that, for very little, did not receive the financial aid. With these two groups of individuals, I estimate the following regression specification:

$$
\begin{gathered}
y_{i b t}=\beta_{1} C C_{i}+\beta_{2} \text { Post }_{t}+\beta_{3}\left(C C_{i} \times \text { Post }_{t}\right)+ \\
\Theta_{i}^{F E}+\Psi X_{i p}+\Omega_{b t}^{F E}+\varepsilon_{i b t}
\end{gathered}
$$

where $y$ is the outcome of person $i$, bank $b$ and time $t$. The outcomes variables $y_{i b t}$ are: (i) The $\log ($ Total Credit +1$)$, (ii) The implicit interest rate and (iii) The $\log$ (Days of arrears). In terms of regressors, $C C_{i}$ captures the individuals status (equal to 1 for treated individuals and 0 for those in the control group) and Post $_{t}$ is a dummy variable that takes the value of 1 after the first implementation of the cash transfer program from the peruvian government and 0 before. I also include individuals fixed effect, bank-borrowers relationship factors and Bank $\times$ Date fixed effects.

I include Bank $\times$ Date fixed effects expressed in the variable $\Omega_{b t}^{F E}$, where date $t$ is recorded in a monthly frequency. This variable was introduced to control the main characteristics of banks that may vary on time such as liquidity, return over assets and the size of bank. This allows me to disentangle banks' supply of loans from individuals' demand for them ${ }^{11}$. Adding Bank $\times$ Date

IFH are in the Ministerial Resolution of the Ministry of Development and Social Inclusion $\mathrm{N}^{\circ}$ 107-2015.

${ }^{11}$ Similar to Jiménez, Ongena, Peydró, and Saurina (2012) and Alfaro, García-Santana, and MoralBenito (2019), I have data of loans from individuals who have demanded in one or more banks, 
fixed effects absorbs possible supply of loans banks have and allows the main coefficient of interest, $\beta_{3}$ to capture the individuals-level differences in treated individuals' outcome variable $y$ compared to that of the control group after the implementation of the financial aid from the peruvian government.

On the other hand, $\Theta_{i}^{F E}$ is introduced to capture idiosyncratic characteristics of each person, such the region where the person lives, gender, among others.

Finally, I include $X_{i p}$ to control possible preferences of a person to deal with a particular bank and absorb specific bank-individuals (observable) relationship factors. Those variables are (i) the length of the relationship between a bank and a person, and (ii) the percentage of credit that a firm was receiving from a bank as of the month previous at the financial aid of the government. That is because if the person only asks for a quote from only one of the banks with which it has a relationship, $\beta_{3}$ could reflect the preference of a person to deal with a particular bank, and not the treated individuals' demand of credit.

With this specification; i.e., the assignment dictated by an observable rule together with the restriction of this assignment near the cutoff, I satisfy the conditional mean zero assumption required for unbiased estimates ( Roberts and Whited - 2012).

that allows me to disentangle demand from supply effects. 


\section{Results}

\section{Cash Transfers}

I make the analysis of the impact of cash transfers on the use of credit during the Covid-19 pandemic. In this sense, I explore a discontinuity in the rule for granting emergency income to the poorest population. Given that my treatment and control groups were assigned as-if-random near the cutoff, my results permit to move forward in the direction of a causal claim. Furthermore, I also support this claim showing the parallel trends (Figure 3) over the 2 groups of individuals, as well as a Placebo and Falsification Test as specified in Roberts and Whited (2012).
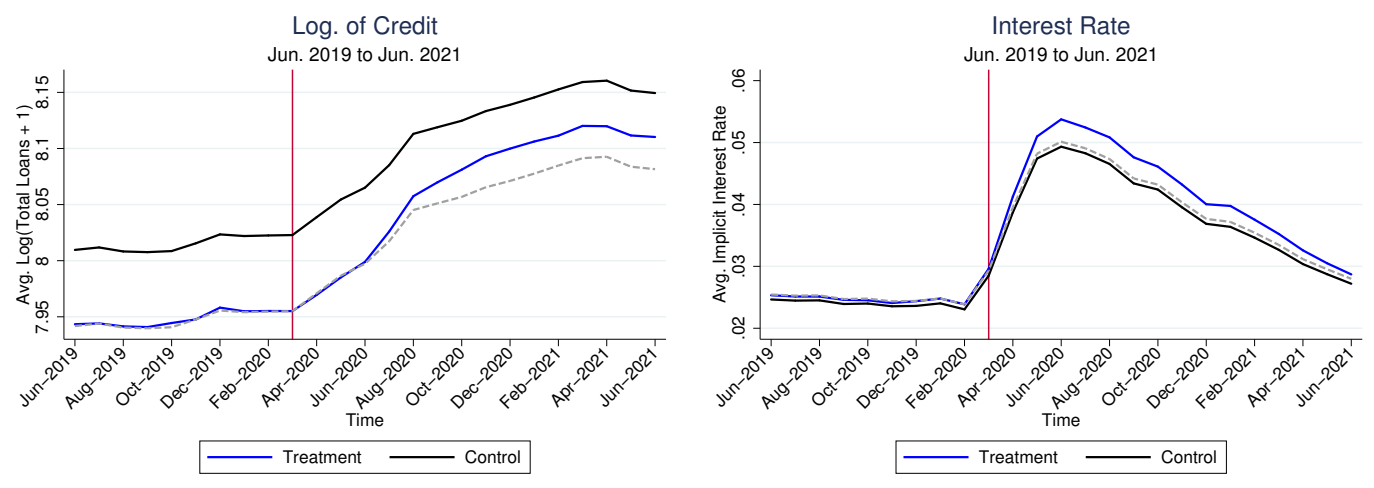

Figure 3: Parallel Trends for Cash Transfers

Note: This figure shows the parallel trends for the credit (in logs) and the interest rates. As is observed, after the first implementation of a cash transfer program in Peru, the credit increases for both groups. However, the increase is remarkably steeper for the treatment group. Situation is similar for interest rates, where there is a greater increase also for the treatment group.

According to Table 4 I observe that, in contrast to individuals who did not receive the cash transfer, individuals who did have an increase in their credit demand by approximately $1.4 \%$ after the announcement of the transfer. This increase could be motivated by the hope that they might receive another cash transfer of the government in the context of the Covid-19 pandemic, what did not necessarily happen ${ }^{12}$. However, what actually happened was an increase in the days of arrears and interest rates of individuals.

\footnotetext{
${ }^{12}$ In fact, the purpose of each one of the first transfers was to include individuals not in-
} 
Table 5 shows that, in contrast to individuals who did not receive the cash transfer, individuals who did had an increase in their arrears by about $3.2 \%$ after the announcement of the first transfer, what represents roughly 2 days of additional arrears. Furthermore, the days of arrears increases to 15 if I only consider individuals who already had some kind of financial problems.

The greater arrears is related to greater interest rates; thus, I observe that, in contrast to individuals who did not receive the cash transfer, individuals who did have an increase in their interest rates by approximately 7.5 basis points after the announcement of the transfer.

This poses a reflection about the importance of good communication of public policies towards individuals, as the government has to be clear in the message behind the implementation of each policy. In the case of Peru, the government did not specify in a proper way that it would be a one-time aid, given the pandemic context ${ }^{13}$. In fact, some believed that they may be beneficiaries, despite the fact that they have already received another subsidy before ${ }^{14}$.

cluded before, what can be observed in the requirements of each subsidy: https://www.gob.pe/ 8895-coronavirus-apoyos-economicos-del-estado-por-el-aislamiento-social-obligatorio.

${ }^{13}$ As was mentioned, requirements were published in the site of the government, which I do not consider an efficient means of communication if the target public is individuals living in poverty. Furthermore, newspapers and newscast mainly mentioned places where the payment of the subsidy could be carried out and target audiences. See: https://gestion.pe/noticias/ yo-me-quedo-en-casa/, https://gestion.pe/noticias/bono-independiente/.

${ }^{14}$ Furthermore, even in subsidies in whose requirements it was allowed to receive the subsidy again, the proportion of individuals included in that group was at most $50 \%$ of that subsidy. See: https://www.ipe.org.pe/portal/ gobierno-alento-confusion-con-tantos-tipos-de-bonos-focalizacion/ 


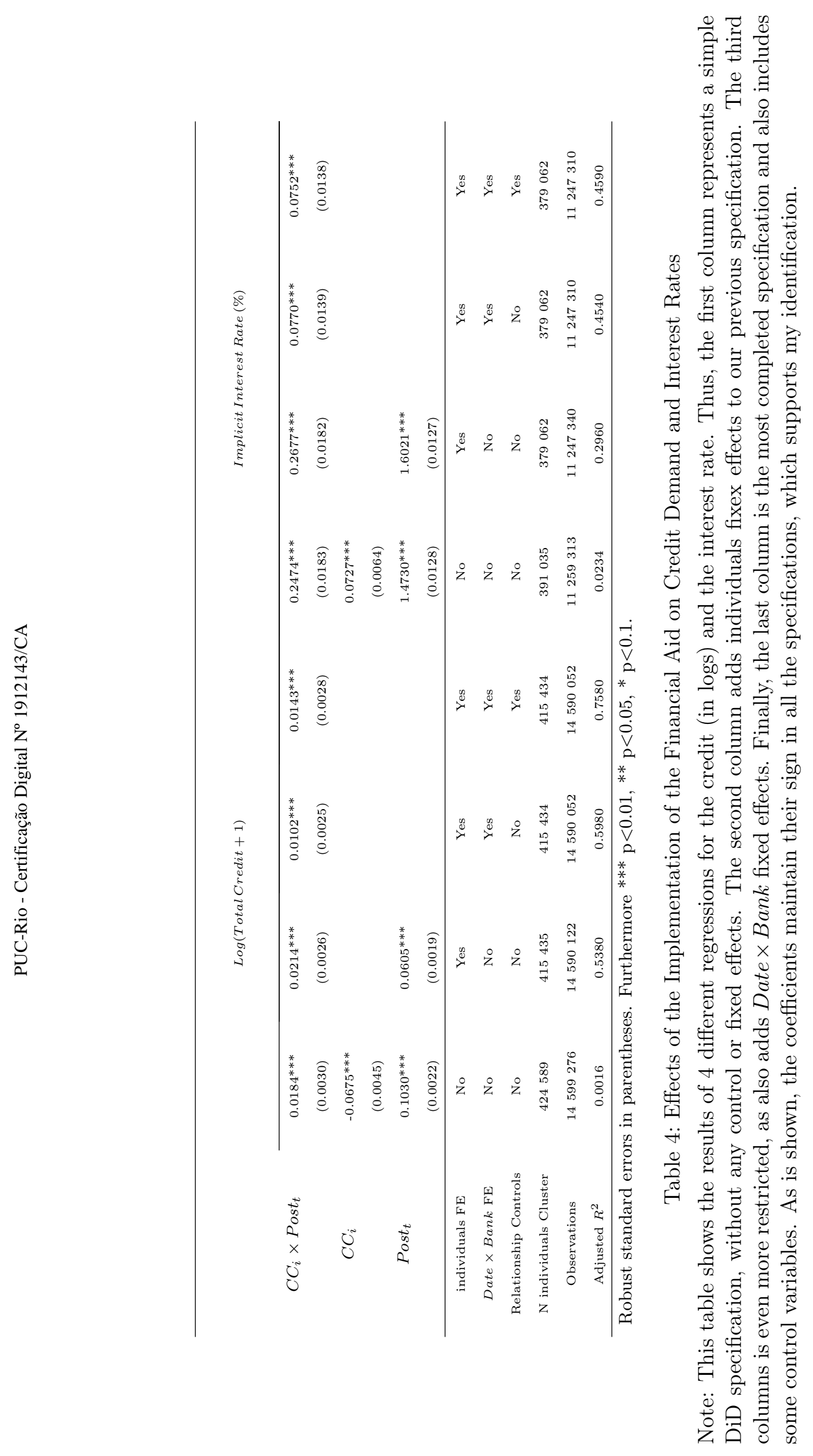




\begin{tabular}{|c|c|c|c|c|}
\hline \multirow{3}{*}{$C C_{i} \times$ Post $_{t}$} & \multicolumn{4}{|c|}{ Log(Days of arrears): } \\
\hline & $0.0106^{* *}$ & $0.0276^{* * *}$ & $0.0301 * * *$ & $0.0302^{* * *}$ \\
\hline & $(0.0041)$ & $(0.0038)$ & $(0.0037)$ & $(0.0037)$ \\
\hline \multirow[t]{2}{*}{$C C_{i}$} & $0.0216^{* * *}$ & & & \\
\hline & $(0.0043)$ & & & \\
\hline \multirow[t]{2}{*}{ Post $_{t}$} & $0.1220^{* * *}$ & $0.3750^{* * *}$ & & \\
\hline & $(0.0030)$ & $(0.0027)$ & & \\
\hline individuals FE & No & Yes & Yes & Yes \\
\hline Date $\times$ Bank FE & No & No & Yes & Yes \\
\hline Relationship Controls & No & No & No & Yes \\
\hline $\mathrm{N}$ individuals Cluster & 424589 & 415435 & 415434 & 415434 \\
\hline Observations & 14599276 & 14590122 & 14590052 & 14590052 \\
\hline Adjusted $R^{2}$ & 0.0015 & 0.5520 & 0.5810 & 0.5810 \\
\hline
\end{tabular}

Robust standard errors in parentheses. Furthermore ${ }^{* * *} \mathrm{p}<0.01,{ }^{* *} \mathrm{p}<0.05,{ }^{*} \mathrm{p}<0.1$.

Table 5: Effects of the Implementation of the Financial Aid on Days of Arrears Note: This table also shows the results of the same 4 regressions but for the days of arrears (in logs). Again, the coefficients maintain their sign in all the specifications, which supports my identification.

\section{Population Heterogeneity}

First, I explore some dimensions of population heterogeneity as an attempt to show the differentiated impact that the covid-19 pandemic had on individuals. To this, I use the same DiD model specified before, where the $C C_{i}$ variable is determined by some characteristics of individuals and Post $t_{t}$ takes the value of 1 since march of 2020, the date the pandemic (and quarantine) began in Peru. The data used to make these regressions is the same of SISFOH, as this database has this information for every individuals. Appendix B has the tables of results for this.

Recently, the United Nations published a work where they pointed out that the pandemic has affected women more than men, specially in terms of employment and income ${ }^{15}$. This is in line with my findings, since I found that, in contrast to men, peruvian women seem to have increased their credit after the arrival of the covid-19 to Perú and the subsequent quarantine decreed by about 4\%. In fact, as a woman is more likely to lose her job due to the pandemic, she is likely to finance her needs through credit, if possible.

With respect to the civil status I can observe that individuals in almost all the cathegories seem to have reduced their credit after the arrival of the covid-

\footnotetext{
${ }^{15}$ For example, in the United States, hundreds of thousands of women, nearly eight times the number of men, left the U.S. workforce in September 2020, according with the government of the US.. See: https://cutt.1y/YRZHJME.
} 
19, in contrast to single individuals. In particular, the greatest coefficients are presented in widower and married individuals, where the reduction in credit is by about $15 \%$ and $12 \%$, respectively. On the other hand, the smallest coefficient is presented in individuals under common-law couples, where the reduction in credit is by about $6.1 \%$.

No clear interpretation is found in the case of education, where individuals with high-school seem to have increased their credit after the arrival of the covid-19 to Perú by about 2.9\%, whereas I can observe a reduction of around $8.8 \%$ in the case of individuals with graduate studies. The analysis was made taking individuals without education as a reference.

In the case of the job sector, there is a consensus in the pattern of credit. It can be observed that, in contrast to individuals who works in the public sector, individuals with jobs in all the other sectors seem to have increased their credit after the arrival of the covid-19 to Perú and the subsequent quarantine decreed, with significant coefficients in almost all the job sectors. In particular, the greatest coefficient is presented individuals in the artisan sector, where the increase of credit is by about $9.3 \%$, whereas the smallest coefficient is presented in the service sector, where the increase of credit is by about $3 \%$.

There is also a clear patter in the case of the geographic region. In this case, it can be observed that, in contrast to individuals who live in Lima, individuals in all the other regions seem to have increased their credit after the arrival of the covid-19 to Perú and the subsequent quarantine decreed. In particular, the greatest coefficients are presented with individuals living in the Highlands, where the increase of credit is by about $11.2 \%$ and $8.4 \%$ por rural and urban, respectively. On the other hand, the smallest coefficient is presented in individuals living in the urban coast, where the increase of credit is by about $3.9 \%$.

Finally, there is also a clear pattern in the case of the age of individuals. Thus, it can be observed that, in contrast to individuals under 25 years old, older individuals seem to have reduced their credit after the arrival of the covid-19 to Perú and the subsequent quarantine decreed. The reduction is greater as age increases and is about $28.6 \%$ for individuals over 65 years of age and only $4.3 \%$ for individuals between 25 and 35 years old. This is in line with a work of the International Labour Organization, where it is highlighted that the impact of the pandemic has been particularly hard on young women, younger youth and youth in lower-income countries ${ }^{16}$. Again, a worse situation due to the pandemic could be related with an increase in the indebtedness of those indivuals most affected.

\footnotetext{
${ }^{16}$ Youth \& Covid-19: Impacts on jobs, education, rights and mental well-being - International Labour Organization.
} 


\section{Special Case: Labor Informality}

It is important to mention that, what was previously shown are based on the data of the final database in which I consider only individuals near the factors' cutoff that differentiate poor individuals from those non-poor; i.e., to this, I only use information of the SISFOH and credit registers. However, with these registers, I can not say anything about the differenciated impact of the covid-19 pandemic on labor informality ${ }^{17}$.

To this purpose, I use the household survey of Perú, an annual survey that is nationally representative, and gives me information about labor informality. In this case, the $C C_{i}$ variable is determined by the condition of labor informality on individuals. Given that the informal condition on labor is not dictated by an observable rule, I can not move these results in the direction of a causal claim; however, my results are robust and pass the parallel trends (Figure 4) and the Falsification Test (Roberts and Whited - 2012) provided in the next subsection.
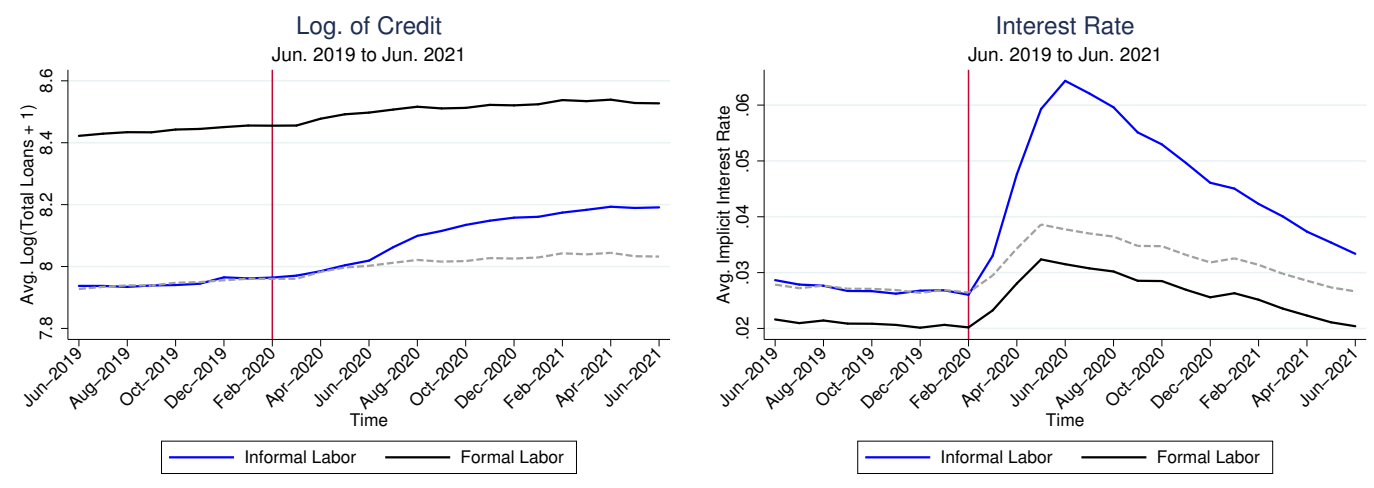

Figure 4: Parallel Trends for Informality

Note: This figure shows the parallel trends for the credit (in logs) and the interest rates for the two groups of individuals: with formal and informal work. Again, a clear difference in trends is presented after March/April of 2020, initial months of the Covid-19 pandemic in Peru.

According to Table 6 I observe that, in contrast to individuals with a formal work, individuals with informal work seem to have an increase in their credit by approximately $5.7 \%$ after the arrival of covid-19 in Peru. This increase could be due to the quarantine decreed since mid-March of 2020, as individuals in the informal sector needed to finance their needs and, without work

\footnotetext{
${ }^{17}$ As Ulyssea, G. (2020), the definition used for informal workers are those who do not have a formal labor contract.
} 
or a fixed monthly income, a greater indebtedness was a possibility. Unfortunately, the total quarantine lasted almost 4 months and, even when some activities resumed in July of that year, the vast majority of jobs that involves the informal sector remained paralyzed for a few more months.

As a result, in contrast to those with a formal work, individuals with an informal work seem to have an increase in their arrears by about $20 \%$ after the arrival of covid-19 in Peru (Table 7). This increase represents roughly 23 days of additional arrears, what finally could be related with an increase in the interest rates of those individuals by about 59.7 basis points. However, the days of arrears increases to 53 if I only consider individuals who already had some kind of financial problems. 


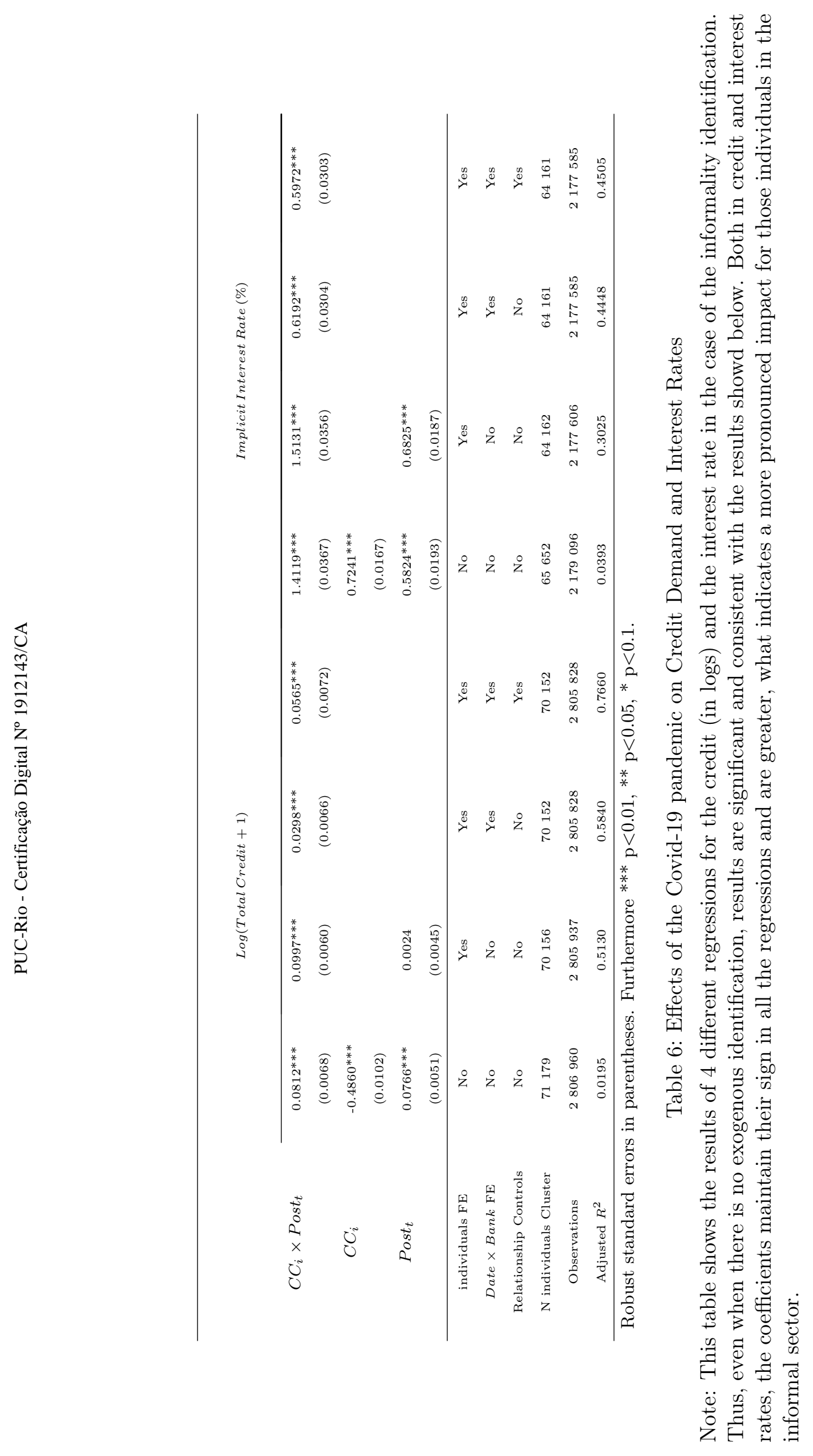




\begin{tabular}{|c|c|c|c|c|}
\hline \multirow[b]{2}{*}{$C C_{i} \times$ Post $_{t}$} & \multicolumn{4}{|c|}{ Log(Days of arrears): } \\
\hline & $\begin{array}{c}0.0644^{* * *} \\
(0.0090)\end{array}$ & $\begin{array}{c}0.1960 * * * \\
(0.0082)\end{array}$ & $\begin{array}{c}0.1992^{* * *} \\
(0.0091)\end{array}$ & $\begin{array}{c}0.1997^{* * *} \\
(0.0091)\end{array}$ \\
\hline$C C_{i}$ & $\begin{array}{c}0.2490^{* * *} \\
(0.0095)\end{array}$ & & & \\
\hline Post $_{t}$ & $\begin{array}{c}0.0746^{* * *} \\
(0.0059)\end{array}$ & $\begin{array}{c}0.2220^{* * *} \\
(0.0055)\end{array}$ & & \\
\hline individuals $\mathrm{FE}$ & No & Yes & Yes & Yes \\
\hline Date $\times$ Bank FE & No & No & Yes & Yes \\
\hline Relationship Controls & No & No & No & Yes \\
\hline $\mathrm{N}$ individuals Cluster & 71179 & 70156 & 70152 & 70152 \\
\hline Observations & 2806960 & 2805937 & 2805828 & 2805828 \\
\hline Adjusted $R^{2}$ & 0.0088 & 0.5560 & 0.5860 & 0.5860 \\
\hline
\end{tabular}

Table 7: Effects of the Covid-19 Pandemic on Days of Arrears

Note: This table also shows the results of the same 4 regressions but for the days of arrears (in logs) in the case of the. informality identification. Again, in this case the coefficients also maintain their sign in all the specifications.

\section{A. Robustness}

Following Roberts and Whited (2012), I repeat the DiD analysis on pre-event months. I falsely assume that the onset of treatment occurs some months before it actually does and repeat the estimation. To this, I work with monthly data from January of 2019 to February of 2020. As Tables 9 and 8 show, the estimated treatment effect is statistically indistinguishable from zero and this ensure that the observed change in my results is more likely due to the treatment, as opposed to some alternative force.

As can be observed, there are no significant coefficients in this regression. Furthermore, the coefficient is near zero, so the impact is zero in any event. 


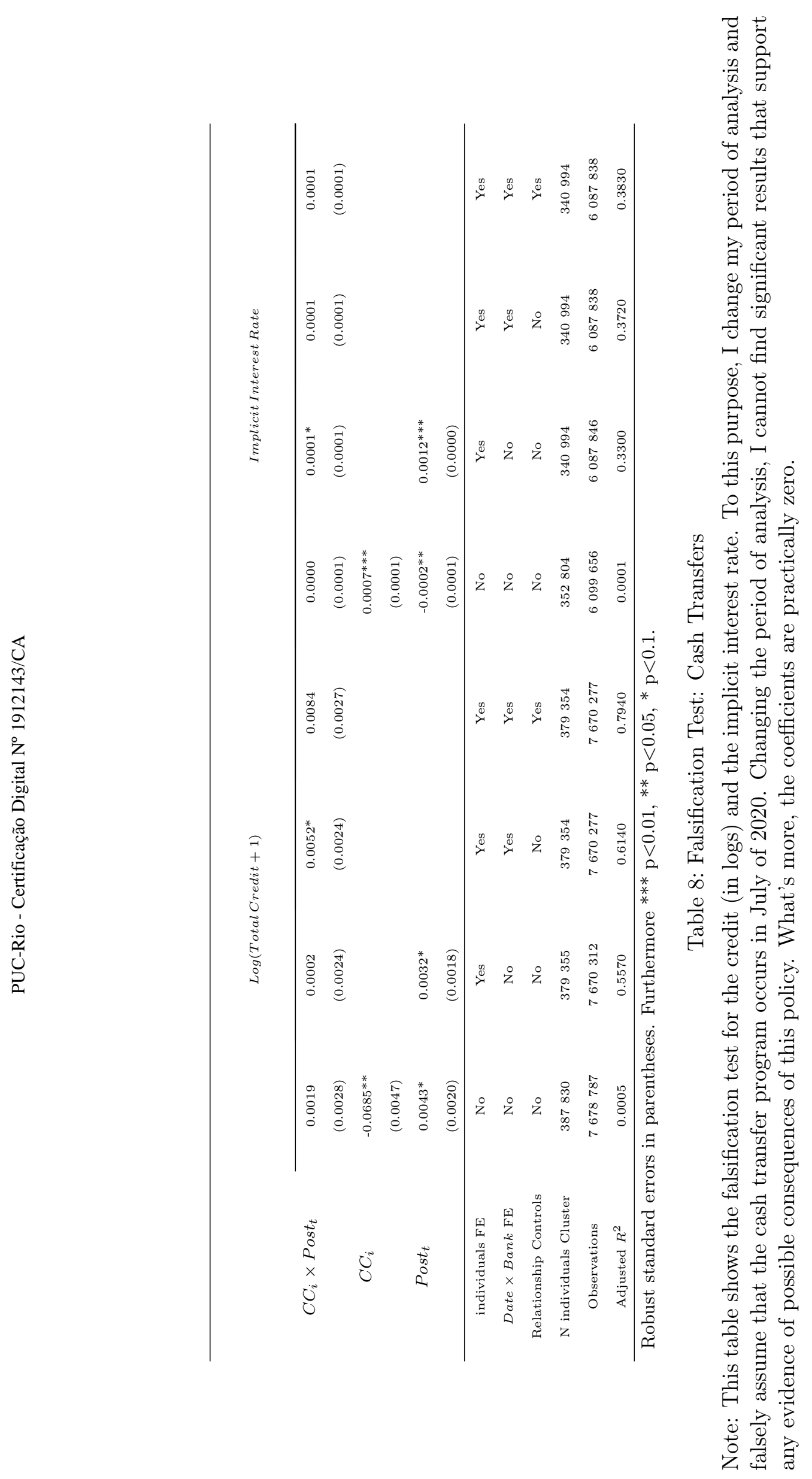




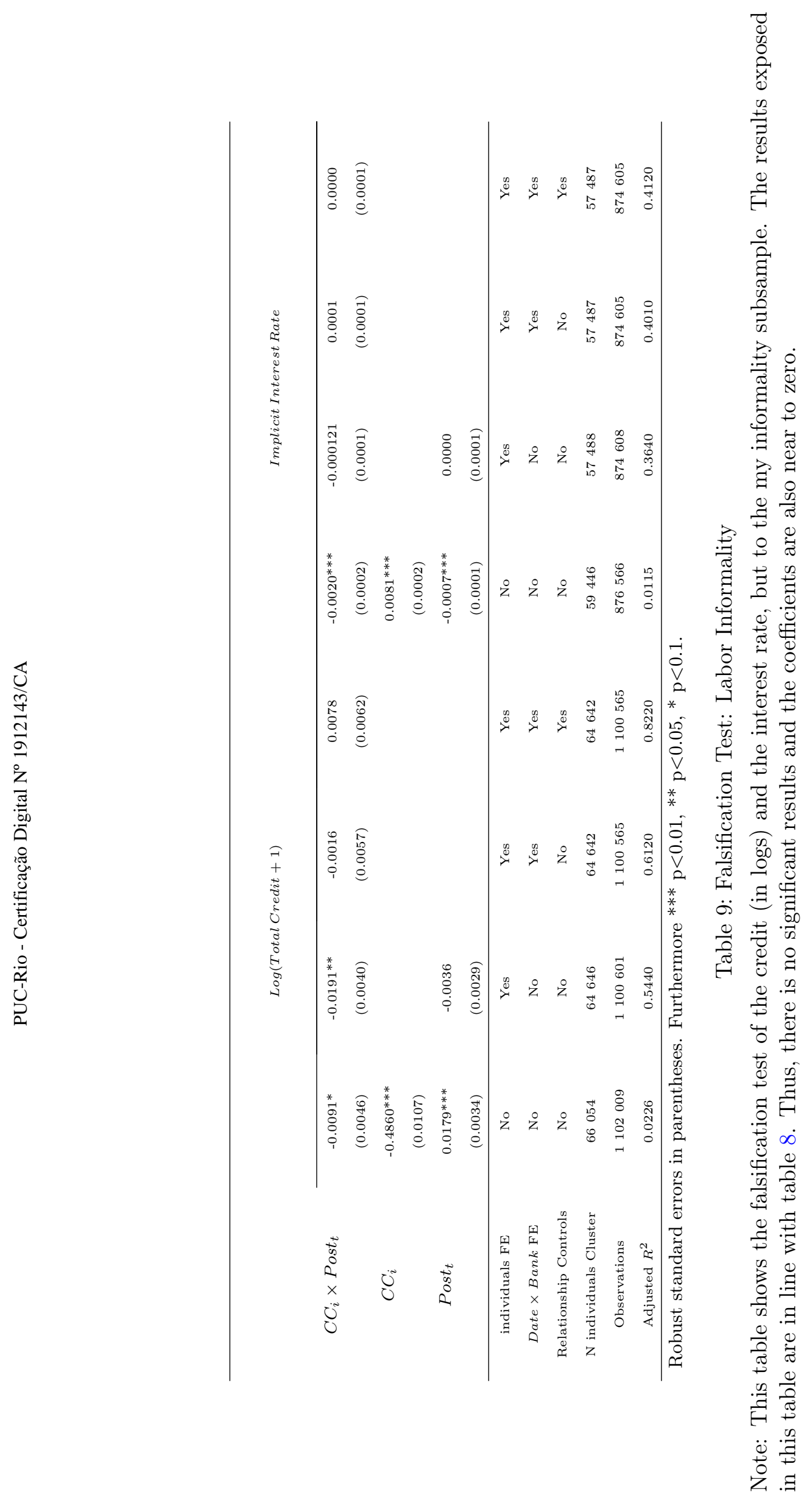


Finally, I also include a placebo test for change in credit in the case of cash transfers. Thus, it can be observed that, changing my treatment group, I no longer have significant coefficients.

\begin{tabular}{|c|c|c|c|c|}
\hline \multirow{3}{*}{$C C_{i} \times$ Post $_{t}$} & \multicolumn{4}{|c|}{$\log ($ Total Credit +1$)$} \\
\hline & -0.0053 & -0.0041 & $0.0101^{*}$ & 0.0029 \\
\hline & $(0.0035)$ & $(0.0031)$ & $(0.0030)$ & $(0.0034)$ \\
\hline \multirow[t]{2}{*}{$C C_{i}$} & $0.2350^{* * *}$ & & & \\
\hline & $(0.0053)$ & & & \\
\hline \multirow[t]{2}{*}{ Post $_{t}$} & $0.1030^{* * *}$ & $0.0605^{* * *}$ & & \\
\hline & $(0.0022)$ & $(0.0019)$ & & \\
\hline individuals $\mathrm{FE}$ & No & Yes & Yes & Yes \\
\hline Date $\times$ Bank $\mathrm{FE}$ & No & No & Yes & Yes \\
\hline Relationship Controls & No & No & No & Yes \\
\hline $\mathrm{N}$ individuals Cluster & 316789 & 310593 & 310591 & 310591 \\
\hline Observations & 11802283 & 11796087 & 11796007 & 11796007 \\
\hline Adjusted $R^{2}$ & 0.0055 & 0.5210 & 0.5900 & 0.7620 \\
\hline
\end{tabular}

Table 10: Placebo test

Note: This table shows the placebo test of the credit (in logs), which complements the falsification test showed above. In this case, I change my treatment group for another one that I am sure did not receive the subsidy through the cash transfer program. In this case, I continue working with the data since January of 2019 to June of 2021. Again, there are no significant coefficients, which gives a lot of support to my identification. 


\section{Conclusion}

In this paper, I showed that individuals who received a monetary subsidy increased their total lending in the financial system, in contrast to those individuals who did not. As this increase could be motivated by the uncertainty about the number of subsidies a person can receive and not by a real fact, I also observed an increase in the days of arrears and interest rates. This poses a reflection about the importance of effective communication of public policies towards the population.

Furthermore, I also explore some dimensions of population heterogeneity, finding a differentiated impact according to certain characteristics of individuals. As examples I have the case of gender (age) where, in contrast to men (young individuals), women (older individuals) increased (decreased) their credit after the arrival of the covid-19 to Perú and the subsequent quarantine decreed. Finally, I also explore the informality condition on individuals, where I show that informal workers seem to have increased their total amount of credit, as well as their days of arrears and interest rates. 


\section{References}

Ashraf, B. (2020). Economic impact of government interventions during the COVID-19 pandemic: International evidence from financial markets. Journal of Behavioral and Experimental Finance.

Aum, S., Yoon, S. and Shin, Y. (2021). COVID-19 doesn't need lockdowns to destroy jobs: The effect of local outbreaks in Korea. Labour Economics

Berriel, T. and Zilberman, E. (2011). Targeting the Poor: A Macroeconomic Analysis of Cash Transfer Programs. Ensaios Econômicos - FGV.

Bertrand, M., Duflo, E. and Mullainathan, S. (2004). How Much Should We Trust Differences-In-Differences Estimates?. The Quarterly Journal of Economics.

Bigio, S., Zhang, M. and Zilberman, E. (2020). Transfers vs Credit Policy: Macroeconomic Policy Trade-offs during Covid-19. NBER working paper.

Céspedes, N. (2017). La demanda de crédito a nivel de personas: RCC conoce a ENAHO. Revista de Estudios Económicos BCRP.

Deb, P., Furceri, D., Ostry, J. and Tawk, N. (2020). The Economic Effects of Covid-19 Containment Measures. CEPR Discussion Paper

Faheem Ahmed, Na'eem Ahmed, Christopher Pissarides and Joseph Stiglitz (2020). Why inequality could spread COVID-19, The Lancet Public Health, Volume 5, Issue 5, 2020.

Fezzi, C. and Fanghella, V. (2020). Real-Time Estimation of the Short-Run Impact of COVID-19 on Economic Activity Using Electricity Market Data. Environmental and Resource Economics

$\mathrm{Hu}, \mathrm{Y}$. (2020). Intersecting ethnic and native-migrant inequalities in the economic impact of the COVID-19 pandemic in the UK. Research in Social Stratification and Mobility.

Shen, H., Fu, M., Pan, H., Yu, Z., and Chen, Y. (2020) The Impact of the COVID-19 Pandemic on Firm Performance, Emerging Markets Finance and Trade.

International Labour Organization (2020). Youth \& COVID-19: Impacts on jobs, education, rights and mental well-being. Survey Report 2020.

Instituto Nacional de Estadística e Informática (2020). Evolución de la Pobreza Monetaria 2009 - 2020. Informe Técnico. 
Ministerio de Desarrollo e Inclusión Social (2015). Metodología para la Determinación de la Clasificación Socioeconómica.

Ravallion, M. (2009). How relevant is targeting to the success of an antipoverty program? The World Bank Research Observer.

Roberts, M. and Whited, T. (2013). Endogeneity in Empirical Corporate Finance. Handbook of the Economics of Finance.

Rume, T. and Didar-Ul, S. (2020). Environmental effects of COVID-19 pandemic and potential strategies of sustainability. Heliyon.

Sacramento, L.C. (2020). Cyclicality of Local Credit Markets and Monetary Policy Transmission. Ebook Prêmio ProPague 2020.

Sarkodie, S.A. and Owusu, P.A. (2021). Impact of COVID-19 pandemic on waste management. Environment, Development and Sustainability.

Ulyssea, Gabriel (2020). Informality: Causes and Consequences for Development. The Annual Review of Economics. 
Appendix A: Coefficient Matrices of the Variables of the 1st and 2nd Factor by Area Cluster

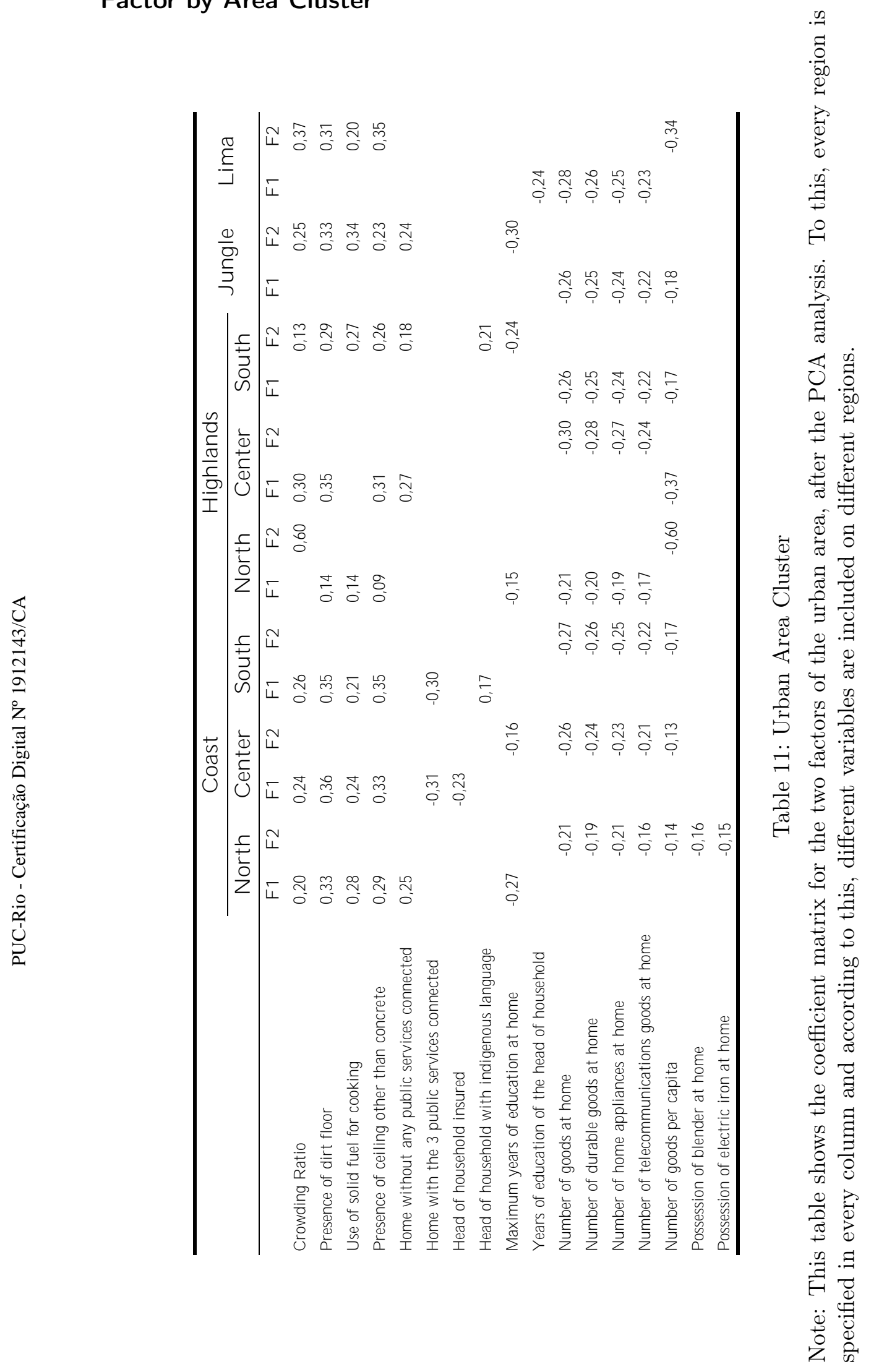




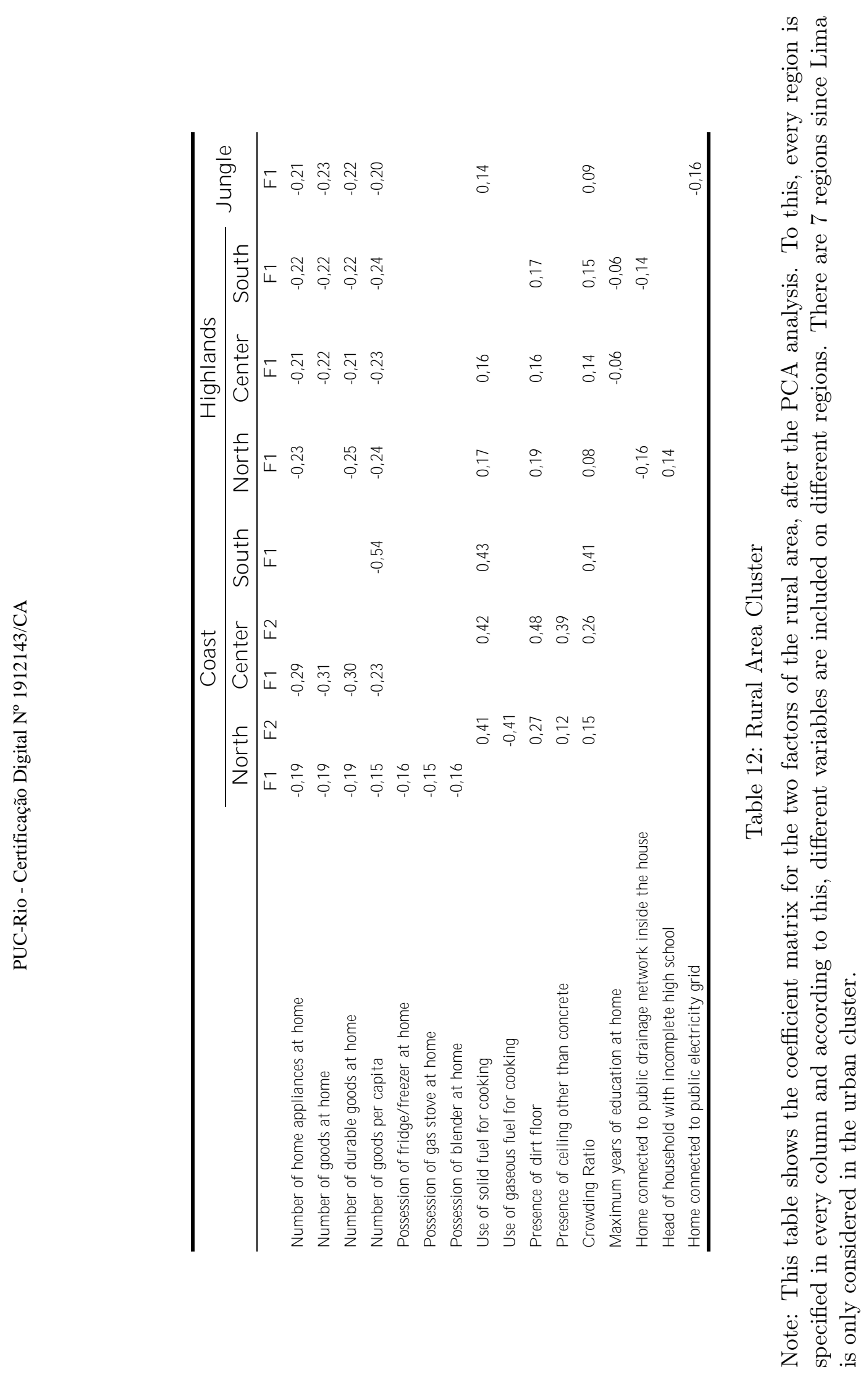




\section{Appendix B: Outputs for Population Heterogeneity}

\begin{tabular}{|c|c|c|c|c|}
\hline \multirow[b]{2}{*}{$C C_{i} \times$ Post $_{t}$} & \multicolumn{4}{|c|}{$\log ($ Total Credit +1$)$} \\
\hline & $\begin{array}{c}-0.0483^{* * *} \\
(0.0030)\end{array}$ & $\begin{array}{c}-0.0671^{* * *} \\
(0.0027)\end{array}$ & $\begin{array}{c}-0.0346 * * * \\
(0.0027)\end{array}$ & $\begin{array}{c}-0.0405^{* * *} \\
(0.0030)\end{array}$ \\
\hline$C C_{i}$ & $\begin{array}{c}0.4460^{* * *} \\
(0.0045)\end{array}$ & & & \\
\hline Post $_{t}$ & $\begin{array}{c}0.1470^{* * *} \\
(0.0023)\end{array}$ & $\begin{array}{c}0.1150^{* * * *} \\
(0.0021)\end{array}$ & & \\
\hline individuals $\mathrm{FE}$ & No & Yes & Yes & Yes \\
\hline Date $\times$ Bank FE & No & No & Yes & Yes \\
\hline Relationship Controls & No & No & No & Yes \\
\hline $\mathrm{N}$ individuals Cluster & 424589 & 415435 & 415434 & 415434 \\
\hline Observations & 14599276 & 14590122 & 14590052 & 14590052 \\
\hline Adjusted $R^{2}$ & 0.0172 & 0.5380 & 0.5980 & 0.7580 \\
\hline
\end{tabular}

Table 13: Gender

Note: This table shows the coefficients for the regression in gender. The analysis is made in contrast to female individuals. 
$\log ($ Tot Credit +1$)$

\begin{tabular}{|c|c|c|c|c|}
\hline$C C_{i} \times$ Post $_{t}$ & & & & \\
\hline Married & $\begin{array}{c}-0.0650 * * * \\
(0.0040)\end{array}$ & $\begin{array}{c}-0.1170^{* * *} \\
(0.0035)\end{array}$ & $\begin{array}{c}-0.0804 * * * \\
(0.0035)\end{array}$ & $\begin{array}{c}-0.1220^{* * *} \\
(0.0039)\end{array}$ \\
\hline Cohabiting & $\begin{array}{c}-0.0221 * * * \\
(0.0042)\end{array}$ & $\begin{array}{c}-0.0416 * * * \\
(0.0037)\end{array}$ & $\begin{array}{c}-0.0400 * * * \\
(0.0035)\end{array}$ & $\begin{array}{c}-0.0609 * * * \\
(0.0041)\end{array}$ \\
\hline Separated & $\begin{array}{c}-0.0167^{* * *} \\
(0.0062)\end{array}$ & $\begin{array}{c}-0.0370^{* * *} \\
(0.0055)\end{array}$ & $\begin{array}{c}-0.0368^{* * *} \\
(0.0053)\end{array}$ & $\begin{array}{c}-0.0709 * * * \\
(0.0061)\end{array}$ \\
\hline Divorced & $\begin{array}{c}-0.0632 * * * \\
(0.0197)\end{array}$ & $\begin{array}{c}-0.0987^{* * *} \\
(0.0174)\end{array}$ & $\begin{array}{c}-0.0544 * * * \\
(0.0168)\end{array}$ & $\begin{array}{c}-0.0990 * * * \\
(0.0187)\end{array}$ \\
\hline Widower & $\begin{array}{c}-0.0665^{* * *} \\
(0.0080)\end{array}$ & $\begin{array}{c}-0.1480 * * * \\
(0.0073)\end{array}$ & $\begin{array}{c}-0.0853^{* * *} \\
(0.0071)\end{array}$ & $\begin{array}{c}-0.1500^{* * *} \\
(0.0081)\end{array}$ \\
\hline individuals $\mathrm{FE}$ & No & Yes & Yes & Yes \\
\hline Date $\times$ Bank $\mathrm{FE}$ & No & No & Yes & Yes \\
\hline Relationship Controls & No & No & No & Yes \\
\hline $\mathrm{N}$ individuals Cluster & 418901 & 410184 & 410183 & 410183 \\
\hline Observations & 14518248 & 14509531 & 14509461 & 14509461 \\
\hline Adjusted $R^{2}$ & 0.0153 & 0.5370 & 0.5970 & 0.7580 \\
\hline
\end{tabular}

Robust standard errors in parentheses. Furthermore ${ }^{* * *} \mathrm{p}<0.01,{ }^{* *} \mathrm{p}<0.05,{ }^{*} \mathrm{p}<0.1$.

\section{Table 14: Civil Status}

Note: This table shows the coefficients for the regression in civil status. The analysis is made in contrast to single individuals. 
$\log ($ Tot Credit +1$)$

\begin{tabular}{|c|c|c|c|c|}
\hline & \multicolumn{4}{|c|}{$\log ($ Tot Credit +1$)$} \\
\hline \multicolumn{5}{|l|}{$C C_{i} \times$ Post $_{t}$} \\
\hline \multirow{2}{*}{ Kinder } & -0.0335 & -0.0180 & -0.0179 & -0.0030 \\
\hline & $(0.0315)$ & $(0.0264)$ & $(0.0259)$ & $(0.0306)$ \\
\hline \multirow{2}{*}{ Primary School } & $-0.0576^{* * *}$ & -0.0095 & -0.0042 & -0.0034 \\
\hline & $(0.0100)$ & $(0.0088)$ & $(0.0085)$ & $(0.0099)$ \\
\hline \multirow{2}{*}{ High School } & $-0.0539 * * *$ & -0.0052 & $0.0265^{* * *}$ & $0.0293^{* * *}$ \\
\hline & $(0.0098)$ & $(0.0087)$ & $(0.0084)$ & $(0.0097)$ \\
\hline Non-university higher & $-0.0971^{* * *}$ & $-0.0652^{* * *}$ & $0.0173^{*}$ & 0.0063 \\
\hline education & $(0.0103)$ & $(0.0091)$ & $(0.0088)$ & $(0.0102)$ \\
\hline \multirow{2}{*}{ Undergraduate studies } & $-0.1060^{* * *}$ & $-0.0843^{* * *}$ & 0.0128 & 0.0003 \\
\hline & $(0.0103)$ & $(0.0092)$ & $(0.0090)$ & $(0.0103)$ \\
\hline \multirow{2}{*}{ Graduate studies } & $-0.1650^{* * *}$ & $-0.1820^{* * *}$ & $-0.0709^{* * *}$ & $-0.0883^{* * *}$ \\
\hline & $(0.0279)$ & $(0.0252)$ & $(0.0239)$ & $(0.0258)$ \\
\hline individuals $\mathrm{FE}$ & No & Yes & Yes & Yes \\
\hline Date $\times$ Bank FE & No & No & Yes & Yes \\
\hline Relationship Controls & No & No & No & Yes \\
\hline N Clusters & 424500 & 415352 & 415351 & 415351 \\
\hline Observations & 14596705 & 14587557 & 14587487 & 14587487 \\
\hline Adjusted $R^{2}$ & 0.0147 & 0.5380 & 0.5980 & 0.7580 \\
\hline
\end{tabular}

Table 15: Level of Education

Note: This table shows the coefficients for the regression in the level of education. The analysis is made in contrast to individuals without any level of education. 
$\log ($ Tot Credit +1$)$

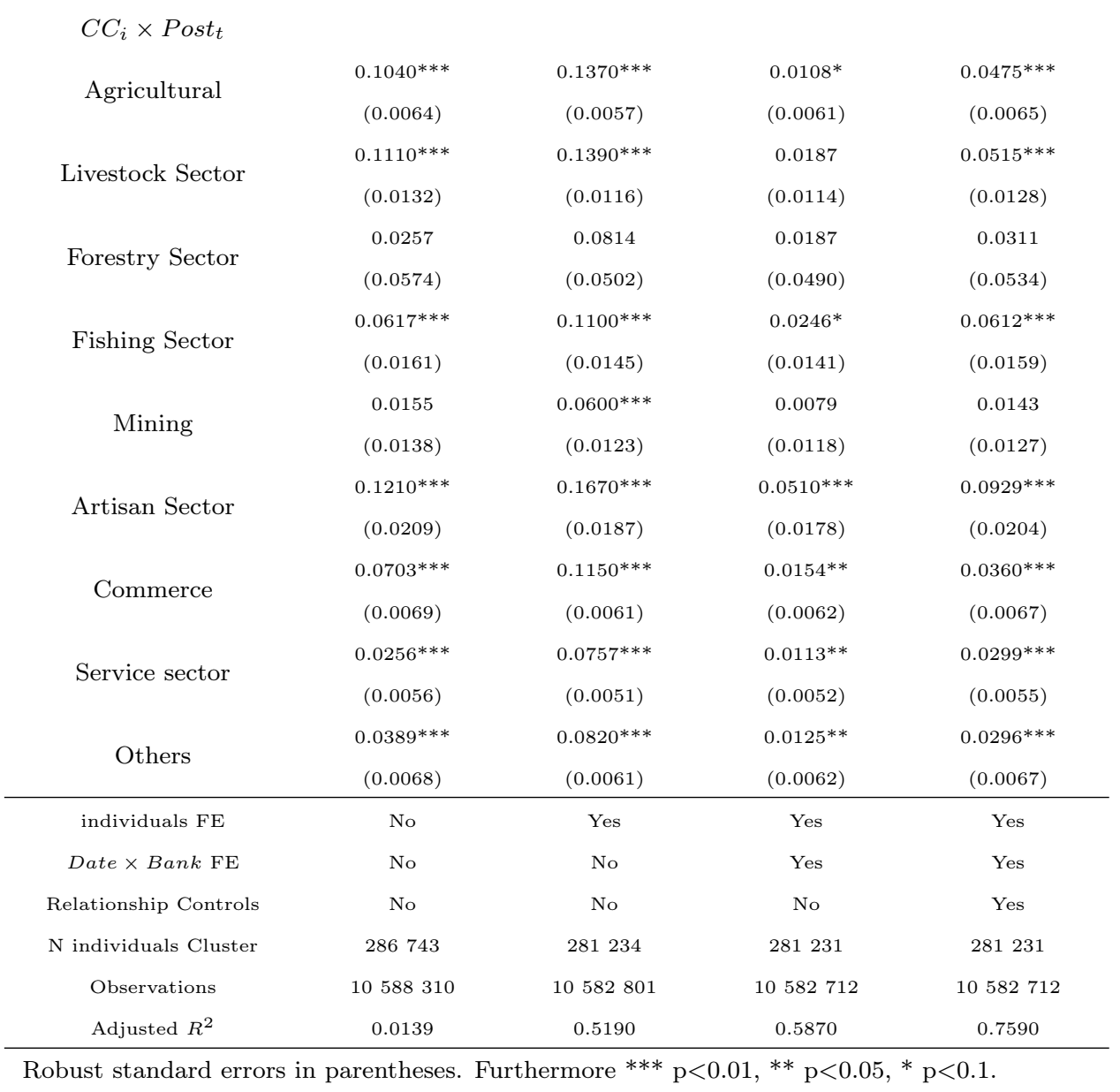

Table 16: Job Sector

Note: This table shows the coefficients for the regression in job sector. The analysis is made in contrast to individuals who work in the public sector. 
$\log ($ Tot Credit +1$)$

\begin{tabular}{|c|c|c|c|c|}
\hline \multicolumn{5}{|l|}{$C C_{i} \times$ Post $_{t}$} \\
\hline Urban Coast & $\begin{array}{c}0.0574^{* * *} \\
(0.0038)\end{array}$ & $\begin{array}{c}0.0702^{* * *} \\
(0.0034)\end{array}$ & $\begin{array}{c}0.0294^{* * *} \\
(0.0035)\end{array}$ & $\begin{array}{c}0.0390 * * * \\
(0.0039)\end{array}$ \\
\hline Urban Highlands & $\begin{array}{c}0.0806 * * * \\
(0.0039)\end{array}$ & $\begin{array}{c}0.0927^{* * *} \\
(0.0035)\end{array}$ & $\begin{array}{c}0.0652^{* * *} \\
(0.0035)\end{array}$ & $\begin{array}{c}0.0838^{* * *} \\
(0.0039)\end{array}$ \\
\hline Urban Jungle & $\begin{array}{l}-0.0135 \\
(0.0156)\end{array}$ & $\begin{array}{c}0.0603^{* * *} \\
(0.0136)\end{array}$ & $\begin{array}{l}0.0230 * \\
(0.0134)\end{array}$ & $\begin{array}{c}0.0540 * * * \\
(0.0158)\end{array}$ \\
\hline Rural Coast & $\begin{array}{c}0.0960 * * * \\
(0.0068)\end{array}$ & $\begin{array}{c}0.1190 * * * \\
(0.0060)\end{array}$ & $\begin{array}{c}0.0424^{* * *} \\
(0.0061)\end{array}$ & $\begin{array}{c}0.0674^{* * *} \\
(0.0069)\end{array}$ \\
\hline Rural Highlands & $\begin{array}{c}0.1320^{* * *} \\
(0.0053)\end{array}$ & $\begin{array}{c}0.1490 * * * \\
(0.0046)\end{array}$ & $\begin{array}{c}0.0644^{* * *} \\
(0.0050)\end{array}$ & $\begin{array}{c}0.1120 * * * \\
(0.0055)\end{array}$ \\
\hline Rural Jungle & $\begin{array}{c}0.0087 \\
(0.0119)\end{array}$ & $\begin{array}{c}0.0841^{* * *} \\
(0.0100)\end{array}$ & $\begin{array}{c}0.0570^{* * *} \\
(0.0100)\end{array}$ & $\begin{array}{c}0.0742^{* * *} \\
(0.0117)\end{array}$ \\
\hline individuals $\mathrm{FE}$ & No & Yes & Yes & Yes \\
\hline Date $\times$ Bank FE & No & No & Yes & Yes \\
\hline Relationship Controls & No & No & No & Yes \\
\hline $\mathrm{N}$ individuals Cluster & 424589 & 415435 & 415434 & 415434 \\
\hline Observations & 14599276 & 14590122 & 14590052 & 14590052 \\
\hline Adjusted $R^{2}$ & 0.0085 & 0.5380 & 0.5980 & 0.7580 \\
\hline
\end{tabular}

Table 17: Geographic Region

Note: This table shows the coefficients for the regression in geographic region. The analysis is made in contrast to individuals living in Lima. 
$\log ($ Tot Credit +1$)$

\begin{tabular}{|c|c|c|c|c|}
\hline \multirow[b]{2}{*}{$C C_{i} \times$ Post $_{t}$} & \multicolumn{4}{|c|}{$\log ($ Tot Credit +1$)$} \\
\hline & & & & \\
\hline age $\in[25,35)$ & $\begin{array}{c}0.0082 \\
(0.0066)\end{array}$ & $\begin{array}{l}-0.0017 \\
(0.0059)\end{array}$ & $\begin{array}{l}0.0126^{* *} \\
(0.0057)\end{array}$ & $\begin{array}{c}-0.0429 * * * \\
(0.0068)\end{array}$ \\
\hline age $\in[35,45)$ & $\begin{array}{c}-0.0574^{* * *} \\
(0.0064)\end{array}$ & $\begin{array}{c}-0.0739 * * * \\
(0.0057)\end{array}$ & $\begin{array}{c}-0.0477^{* * *} \\
(0.0055)\end{array}$ & $\begin{array}{c}-0.1270 * * * \\
(0.0066)\end{array}$ \\
\hline age $\in[45,55)$ & $\begin{array}{c}-0.0797^{* * *} \\
(0.0063)\end{array}$ & $\begin{array}{c}-0.1160 * * * \\
(0.0056)\end{array}$ & $\begin{array}{c}-0.0765^{* * *} \\
(0.0055)\end{array}$ & $\begin{array}{c}-0.1670 * * * \\
(0.0065)\end{array}$ \\
\hline age $\in[55,65)$ & $\begin{array}{c}-0.0983^{* * *} \\
(0.0065)\end{array}$ & $\begin{array}{c}-0.1510^{* * *} \\
(0.0057)\end{array}$ & $\begin{array}{c}-0.1050^{* * *} \\
(0.0057)\end{array}$ & $\begin{array}{c}-0.2050 * * * \\
(0.0067)\end{array}$ \\
\hline age $>65$ & $\begin{array}{c}-0.1440 * * * \\
(0.0068)\end{array}$ & $\begin{array}{c}-0.2450 * * * \\
(0.0060)\end{array}$ & $\begin{array}{c}-0.1470 * * * \\
(0.0061)\end{array}$ & $\begin{array}{c}-0.2860 * * * \\
(0.0071)\end{array}$ \\
\hline individuals $\mathrm{FE}$ & No & Yes & Yes & Yes \\
\hline Date $\times$ Bank FE & No & No & Yes & Yes \\
\hline $\begin{array}{c}\text { Relationship } \\
\text { Controls }\end{array}$ & No & No & No & Yes \\
\hline $\begin{array}{l}\mathrm{N} \text { individuals } \\
\text { Cluster }\end{array}$ & 424589 & 415435 & 415434 & 415434 \\
\hline Observations & 14599276 & 14590122 & 14590052 & 14590052 \\
\hline Adjusted $R^{2}$ & 0.0220 & 0.5390 & 0.5980 & 0.7580 \\
\hline
\end{tabular}

\section{Table 18: Age}

Note: This table shows the coefficients for the regression in age. The analysis is made in contrast to individuals under 25 years old, who represents the youngest population in my sample. 